\title{
OXALATE: FROM THE ENVIRONMENT TO KIDNEY STONES
}

\author{
Hrvoje BRZICA ${ }^{1}$, Davorka BRELJAK ${ }^{2}$, Birgitta C BURCKHARDT ${ }^{3}$, Gerhard BURCKHARDT ${ }^{3}$, \\ and Ivan SABOLIĆ ${ }^{2}$
}

Department of Anatomy, Faculty of Veterinary Medicine, University of Zagreb ${ }^{1}$, Unit of Molecular Toxicology, Institute for Medical Research and Occupational Health, Zagreb, Croatia ${ }^{2}$; Center of Physiology and Pathophysiology, Department of Vegetative Physiology and Pathophysiology, University of Göttingen, Göttingen, Germany ${ }^{3}$

Received in July 2013

CrossChecked in July 2013

Accepted in October 2013

\begin{abstract}
Oxalate urolithiasis (nephrolithiasis) is the most frequent type of kidney stone disease. Epidemiological research has shown that urolithiasis is approximately twice as common in men as in women, but the underlying mechanism of this sex-related prevalence is unclear. Oxalate in the organism partially originate from food (exogenous oxalate) and largely as a metabolic end-product from numerous precursors generated mainly in the liver (endogenous oxalate). Oxalate concentrations in plasma and urine can be modified by various foodstuffs, which can interact in positively or negatively by affecting oxalate absorption, excretion, and/or its metabolic pathways. Oxalate is mostly removed from blood by kidneys and partially via bile and intestinal excretion. In the kidneys, after reaching certain conditions, such as high tubular concentration and damaged integrity of the tubule epithelium, oxalate can precipitate and initiate the formation of stones. Recent studies have indicated the importance of the $\underline{\text { SoLute }}$ Carrier 26 (SLC26) family of membrane transporters for handling oxalate. Two members of this family [ $\underline{\text { Sulfate }}$ Anion Transporter 1 (SAT-1; SLC26A1) and Chloride/Formate EXchanger (CFEX; SLC26A6)] may contribute to oxalate transport in the intestine, liver, and kidneys. Malfunction or absence of SAT-1 or CFEX has been associated with hyperoxaluria and urolithiasis. However, numerous questions regarding their roles in oxalate transport in the respective organs and male-prevalent urolithiasis, as well as the role of sex hormones in the expression of these transporters at the level of mRNA and protein, still remain to be answered.
\end{abstract}

KEY WORDS: calcium, CFEX, kidney stone disease, membrane transporters, nephrolithiasis, organic anions, SAT-1, SLC26A1, SLC26A6, sex differences, urolithiasis

\section{Kidney stones}

Urolithiasis or kidney stone disease (KSD) is a health condition that is rarely life-threatening, but has severe morbidity with a potential lifetime risk for up to $13 \%$ of the general population. In most cases, kidney stones [mostly calcium $\left(\mathrm{Ca}^{2+}\right)$ salts] start to build up in adults when the skeleton is fully formed and the amount of excreted $\mathrm{Ca}^{2+}$ rises, e.g. when a large amount of $\mathrm{Ca}^{2+}$ and/or other metabolites is excreted in a small volume of urine because of the physiological need to conserve water (1). The onset of urolithiasis usually follows the ingestion and/or production of high amounts of main stone-forming compounds, such as oxalate. However, while the ingestion of oxalate-rich food is easily preventable, other urolithiasis-associated factors are more or less veiled and include various genetic mutations that alter general metabolism and homeostasis (2). In addition, 
some well-known systemic disorders, such as obesity or type 2 diabetes mellitus, significantly increase the incidence of urolithiasis (3).

The crucial moment in the pathophysiology of kidney stones is the formation of crystals in the tubular fluid or urine. Crystallisation occurs when the crystalforming materials, such as calcium oxalate $(\mathrm{CaOx})$, calcium phosphate $(\mathrm{CaP})$ or uric acid reach their upper metastable limits, which result in first solid phase precipitations, then grow, aggregate, and finally form stones (4). All people tend to develop these crystals. However, populations prone to disease have larger and coarser crystals, leading to haematuria, pain, and, if not diagnosed on time, formation of sand-like material, gravel, and stones. These stones are basically crystals embedded in protein complexes. The most abundant are stones made of $\mathrm{CaOx}$ monohydrate or dehydrate, which are more or less mixed with apatite (phosphate-based minerals), brushite (CaP dihydrate), or urate (uric acid). Rare and uncommon stones are predominantly constituted of $\mathrm{CaP}$, cystine, struvite (ammonium magnesium phosphate), ammonium salts, and sometimes therapeutic drugs (5). Over 70 compounds were identified in a study on $>10,500$ stones; $\mathrm{CaOx}$ was the predominant compound present in $\sim 87 \%$ of cases, followed by $\mathrm{CaP}(\sim 80 \%)$ and purines ( 19\%) (6). In another study (7), approx. 70,000 stones were analyzed during a 10 -year period and nearly $80 \%$ were built from $\mathrm{CaOx}$ and/or brushite, $\sim 7 \%$ mainly from carbonate and various apatites, $\sim 5 \%$ from urate, and $\sim 1 \%$ from cystine. These data indicate that elevating the concentrations of certain compounds in urine can trigger the onset of KSD.

Although it has been proposed that hyperoxaluria could be significantly more important for the formation of $\mathrm{CaOx}$ stones than hypercalciuria (8), others have concluded that oxalate is most likely a less important contributor under physiological conditions, because oxalate secretion is relatively small compared to the secretion of calcium (5). However, it has been established that rises in urine oxalate concentrations elevate the potential for stone formation (5). Recent studies have deemed oxalate and $\mathrm{Ca}^{2+}$ equally responsible for forming $\mathrm{CaOx}$ stones (9). Along with urine $\mathrm{Ca}^{2+}$ and oxalate levels, urine volume also plays an important role in the onset of $\mathrm{CaOx}$ supersaturation. While the majority of affected patients show no signs of metabolic disorders that could lead to $\mathrm{CaOx}$ supersaturation (idiopathic stone formers), others suffer from hyperparathyroidism or other $\mathrm{Ca}^{2+}$-related metabolic disorders, inflammatory bowel disease, or inherited disorders of oxalate metabolism (10).

\section{Sources of oxalate in the organism}

As shown schematically in Figure 1, oxalate in the mammalian body originates from two sources. Most of body oxalate is a metabolic end-product generated largely in the liver and represents $85 \%$ to $90 \%$ of the

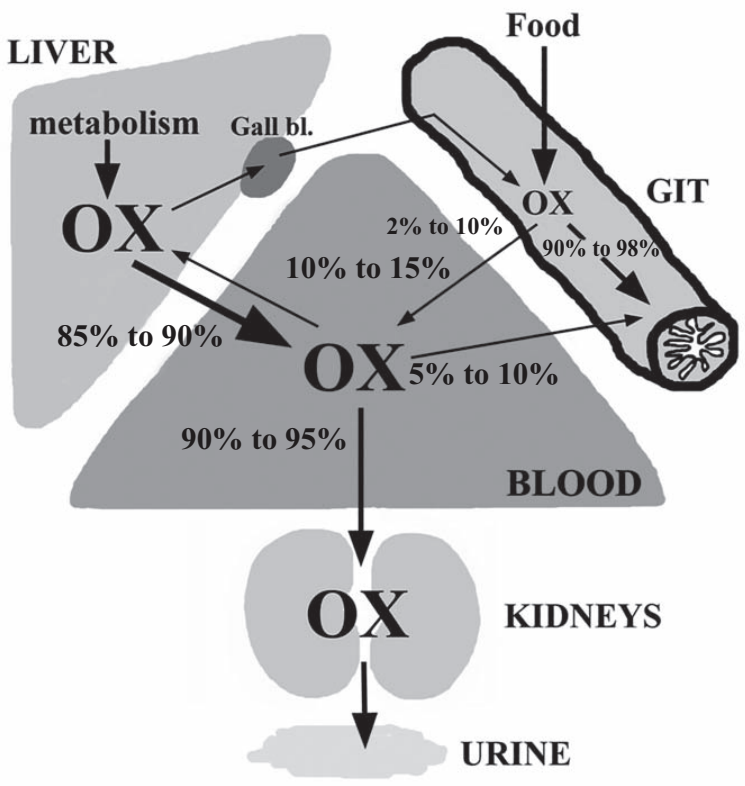

Figure 1 Pathways of oxalate handling in the mammalian body. In physiological conditions, oxalate is partially absorbed from food (exogenous oxalate) in gastrointestinal tract (GIT) and largely produced by metabolism in the liver (endogenous oxalate). Oxalate in food is absorbed in a minor proportion (2\% to 10 $\%)$, whereas most (90\% to $98 \%$ ) is used up as an energy source by the intestinal bacterial or eliminated in feces. A minor proportion of endogenous oxalate in hepatocytes is eliminated by secretion in bile. Both endogenous and exogenous oxalate contributes to total blood oxalate, $85 \%$ to $90 \%$ being from endogenous and $10 \%$ to $15 \%$ from exogenous sources. Most blood oxalate is removed from the organism, largely $190 \%$ to $95 \%$ ) by excretion (ultrafiltration and secretion) in the kidneys, and the rest (5\% to $10 \%$ ) by secretion in intestine. A minor proportion returns to the hepatocytes and thus continuously recycles by enterohepatic circulation. This general pattern is slightly modulated during elevated oxalate concentration in blood, and is significantly changed during chronic renal failure. When the oxalate concentration is increased, proximal tubule epithelium actively transports oxalate from blood into the tubule fluid, thus increasing the amount of excreted oxalate. On the other side, during chronic renal failure, the glomerular filtration rate is reduced, and the expression of oxalate transporters in proximal tubules is downregulated, resulting in diminished elimination of oxalate via urine. As a compensation, the intestines become the site of elevated oxalate secretion and loss via feces. Modified from $(11,12,13)$. 
total oxalate circulating in blood (endogenous oxalate). An unknown proportion of the liver-produced oxalate is removed via bile secretion. The remainder (10\% to $15 \%$ ) of blood oxalate (exogenous oxalate) originates from the absorption of food in the gastrointestinal tract (11-13). The ratio between liver-generated and absorption-related sources depends on oxalate content in ingested food (11). Both sources have a potentially important role in increasing oxalate concentrations in plasma and urine. The bulk ( $90 \%$ to $95 \%$ ) of circulating oxalate is ultimately excreted by the kidneys, whereas some $5 \%$ to $10 \%$ of blood oxalate is excreted in the terminal parts of the small intestine and colon.

Only a small part of the total amount of oxalate in food $(2 \%$ to $10 \%)$ is absorbed (which, however, contributes to $10 \%$ to $15 \%$ of the total blood oxalate), whereas the bulk ( $90 \%$ to $98 \%$ ) is retained in the intestine. To determine the food-related oxalate intake, various foodstuffs have been tested for oxalate content. Oxalate is present in different plant parts and in different quantities, the highest content being $15 \%$ to $20 \%$ of plant total dry weight (14). Spinach and other leafy vegetables are among the leading plants in this respect, with varying concentrations of oxalate as the plant matures. Chocolate, tea, vegetable juice, as well as cranberry and orange juices, were determined among the other notable oxalate sources. However, only spinach and other leafy vegetables are capable of actually inducing hyperoxaluria and, potentially, KSD (15-17). Certain spices can also be a high source of oxalate, particularly cinnamon and turmeric, both of which are often recommended as healthy supplements that benefit the organism. Although both are rich in oxalate, due to different ratios of soluble and non-soluble oxalate, only turmeric significantly increases urine oxalate and thus represents a potential risk factor for urolithiasis (18). When comparing food consumption with regard to stone formers and nonformers, it has been established that stone formers consume significantly higher amounts of proteins (of both plant and animal origin) and purines (19).

The bulk of oxalate absorption, which can be modulated by $\mathrm{Ca}^{2+}, \mathrm{Mg}^{2+}$, and fibers in ingested food, occurs in proximal parts of the digestive tract $1 \mathrm{~h}$ to $8 \mathrm{~h}$ after ingestion (20-22), with two distinct peaks at $40 \mathrm{~min}$ and $120 \mathrm{~min}$ (13). In humans, the daily oxalate intake reportedly ranges between $44 \mathrm{mg}$ per day and $352 \mathrm{mg}$ per day, with an average of $130 \mathrm{mg}$ to $152 \mathrm{mg}$ per day $(23,24)$. However, the intestinal absorption of oxalate does not follow the ingested amount of this compound linearly; the highest ingestion/absorption ratio takes place at an ingested dose of $50 \mathrm{mg}$ per day, while at higher doses (up to $250 \mathrm{mg}$ per day), the overall absorption is higher but the ingestion/ absorption ratio significantly lower (25).

Exogenous oxalate has long been assumed to significantly contribute to hyperoxaluria. However, the current opinion is that hyperoxaluria is the result of a combination of increases in both the endogenous production and intestinal absorption of oxalate (21). Some studies have indicated that exogenous oxalate does not play any significant role in stone formation. For instance, Tiselius et al. (26) found no significant difference in urine excretion of ${ }^{14} \mathrm{C}$-oxalate between healthy patients and patients suffering from "idiopathic" KSD. However, patients with ileocecal resection and a jejunoileal bypass showed higher intestinal absorption and urine excretion of oxalate, indicating that oxalate absorption does not dependent solely on the amount ingested. These differences in oxalate absorption could be due to the action of the oxalatedegrading gram negative bacteria Oxalobacter formigenes ( $O$. formigenes), originally discovered in the rumen of cattle (27). Consequently, studies on cultured bacteria obtained from human feces were conducted, indicating that, while faecal bacteria from healthy patients degraded oxalate in rates of $0.6 \mu \mathrm{mol}$ $\mathrm{g}^{-1} \mathrm{~h}^{-1}$ to $4.8 \mu \mathrm{mol} \mathrm{g}^{-1} \mathrm{~h}^{-1}$, bacteria obtained from patients with a jejunoileal bypass had significantly lower rates, i.e. $\leq 0.006 \mu \mathrm{mol} \mathrm{g}^{-1} \mathrm{~h}^{-1}$, thus proving that oxalate degradation by these bacteria could be a key factor in limiting oxalate absorption by contributing to its degradation prior to absorption (28). The importance of these bacteria for oxalate degradation was further demonstrated in a study on guinea pigs (29), where the control group and the group adapted to higher oxalate intake were injected with increasing amounts of ${ }^{14} \mathrm{C}$-oxalate into the cecum. The oxalateadapted group excreted $\sim 2 \%$ of the radiolabeled oxalate in the urine, whereas the control animals excreted much higher amounts of oxalate at lower doses of ${ }^{14} \mathrm{C}$-oxalate, but could not survive higher doses. It was also demonstrated that the application of antibiotics in oxalate-adapted animals increased the rate of oxalate excretion in urine. Recent findings have also indicated a beneficial role for these bacteria in preventing recurrent oxalate stones; individuals who had been colonized with $O$. formigenes had a $\sim 70 \%$ reduced chance to develop KSD (30).

The ingestion of $\mathrm{Ca}^{2+}$ has long been assumed to be a limiting factor for oxalate absorption and/or 
excretion. A negative correlation was established between ingested $\mathrm{Ca}^{2+}$ and absorption of ingested oxalate by demonstrating that a reduction in the amount of ingested $\mathrm{Ca}^{2+}$ promoted the absorption of oxalate (31), and vice versa, higher concentrations of $\mathrm{Ca}^{2+}$ in food reduced the absorption of oxalate $(23,25$, 32). $\mathrm{Ca}^{2+}$ and oxalate are largely absorbed separately, but they can also be absorbed together in the form of the small and neutral salt, $\mathrm{CaOx}$, as already shown in rats (33). Carbonate, citrate, and malate calcium salts in food have similar effects to $\mathrm{Ca}^{2+}$. In their presence, the absorption of oxalate significantly reduced, while the levels of endogenous oxalate remained the same (34). In addition to $\mathrm{Ca}^{2+}, \mathrm{Mg}^{2+}$ was also proven to modulate oxalate absorption in humans; the control group absorbed $\sim 14 \%$ of the ingested oxalate, while the group consuming calcium carbonate and magnesium oxide absorbed $\sim 5 \%$ and $\sim 8 \%$ of the ingested oxalate (35). In contrast, $\mathrm{Mg}^{2+}$ did not have a major impact on urinary oxalate excretion (23).

Bile salts can directly influence the amount of absorbed oxalate in the intestine, and their effect exhibits certain segmental and species variations. In rats, a single pass infusion of $10 \mathrm{mmol} \mathrm{L}^{-1}$ taurocholate (main salt in rat bile) decreased oxalate absorption in the jejunum and colon, while absorption in the ileum remained unchanged (36). The opposite was found for humans; small doses of chenodeoxycholic acid had no effect on oxalate absorption, while higher doses (up to $2 \mathrm{~g}$ per day) increased both intestinal oxalate absorption and urine excretion (37). Bile acids/salts apparently inhibit precipitation of $\mathrm{CaOx}$ in vitro (38) and therefore change the ratio between free $\mathrm{Ca}^{2+}$, oxalate, and $\mathrm{CaOx}$ complexes in the intestine, which may affect the levels of oxalate in plasma and urine. However, recent studies have cleared the dietary intake of oxalate as a major risk factor for urolithiasis, thus granting exogenous oxalate only a limited role in the possible formation of "idiopathic" oxalate stones (39).

Endogenous oxalate is an end-product of liver metabolism. There is no evidence of subsequent anabolic or catabolic oxalate conversion in the mammalian organism (14). The pathways of the metabolic conversion of various oxalate precursors into oxalate in hepatocytes are shown in Figure 2. Some of these metabolic processes take place in peroxisomes and some in the cell cytoplasm. Endogenous oxalate derives from two main sources: ascorbic acid and glyoxylate. Although ascorbic acid accounts for $\sim 30 \%$ of metabolically generated and excreted oxalate, its exact metabolic pathway is still unknown. The bulk of oxalate production comes from glyoxylate oxidation, with glycolate as the main source (40). These metabolic reactions are catalysed by several key enzymes, including alcohol dehydrogenase 1 (ADH-1), lactate dehydrogenase (LDH), hydroxyacid oxidase 1 (HAO-1), xantine oxidase (XO), alanineglyoxylate aminotransferase (AGAT), and glyoxylate reductase (GRHPR). Malfunctions in the activities or deficient expression of these enzymes can change the metabolic conversion of various oxalate precursors $(14,41,42)$. Several mutations are known to directly influence oxalate producing pathways and significantly contribute to hyperoxalemia and hyperoxaluria. Mutations in the gene encoding AGAT misdirect this enzyme from peroxisomes into mitochondria. This prevents the conversion of glyoxylate to alanine and enables its conversion to oxalate in toto (43). In addition to ascorbic acid and glyoxylate, other compounds, such as various amino acids (tryptophan, phenylalanine, tyrosine), creatinine, purines, and even glucose or other carbohydrates, can also serve as oxalate precursors (14). Various conditions influence and regulate the pathways of oxalate synthesis. One important parameter is intracellular $\mathrm{pH}$, which affects the activity of certain key enzymes. For example, the activity of glycolate oxidase (HAO-1) is $\mathrm{pH}$ sensitive, being higher at $\mathrm{pH} 7.7$ than at $\mathrm{pH} 8.3$ (44), and even higher in isolated peroxisomes at $\mathrm{pH}$ from 6 to 7 (40), which corresponds to physiological $\mathrm{pH}$ in hepatocytes at $\sim 7.1$ (45).

\section{Formation of oxalate crystals and onset of KSD}

When the levels of oxalate and other factors in the urinary system reach the upper metastable limits that enable the formation of crystals, additional prerequisits seem to be needed before stones start to form. Damage to the cell membranes of renal tubules is one of the most important factors initiating stone formation. Given the fact that the growth time for a crystal to reach an obstructing diameter of $\sim 200 \mu \mathrm{m}$ is at least $1.5 \mathrm{~h}$ (46), it is highly unlikely that a crystal would attach to a healthy tubule with unobstructed urine flow $(47,48)$. A crystal is more likely to attach and obstruct the urine flow if the primary injury is located in the anatomically narrow part of the tubule $(46,48)$. Experiments in vitro, such as the one with MDCK cells (Madin-Darby canine kidney; cells with properties of distal tubule epithelial cells) (49), provided support for this theory. When $\mathrm{CaOx}$ monohydrate crystals were administered in healthy cell cultures, no crystals were found attached to the 
cell surface. However, after damaging the monolayer by scraping, crystal adhesion was observed in cells surrounding the wound but not in healthy (undamaged) parts of the culture. After the wound had repaired, the healed monolayer showed no attached crystals. However, experimental models in vitro often differ from in vivo conditions, and the data from different experimental models probably paint a more accurate picture of what actually does occur in the mammalian kidneys. In in vitro models, it is important to use whole urine since samples after urine fractionation were found by some studies to inhibit the attachment of $\mathrm{CaOx}$ monohydrate crystals to MDCK cells (49). Furthermore, in studying optimal conditions for inducing urolithiasis in vitro, most experimental protocols have used very high doses of relevant compounds, whereas in experimental models of urolithiasis in rats in vivo, low doses of possible inducers were deliberately used in order to generate situations relevant for patients through their lifetime. In one such model, a low dose of ethylene glycol (EG, $0.5 \%$ in water) was applied to rats p.o. without or with three different doses of the nephrotoxin hexachloro-1,3-butadiene (HCBD; $10 \mathrm{mg} \mathrm{kg}^{-1}$, $25 \mathrm{mg} \mathrm{kg}^{-1}$, and $50 \mathrm{mg} \mathrm{kg}^{-1}$, i.p.); mild oxaluria was observed in all four conditions, but crystaluria and apoptosis were demonstrated only in rats treated with both EG and HCBD. In addition, crystaluria also appeared dose-dependent after injecting HCBD alone and then abated with time, indicating that, in addition to oxalate, the formation of urinary crystals also requires a tubular damaging agent (50).

Oxalate crystals, composed of $\mathrm{KOx}$ or $\mathrm{CaOx}$ monohydrate, can directly damage MDCK cells in a culture. The presence of crystals caused a loss of cells and elevated levels of cellular enzymes in the medium. Moreover, when both kinds of oxalate crystals were used together, they exhibited synergic action in damaging cells (51). Further experiments on MDCK and LLC-PK1 (pig kidney epithelial cells with properties of proximal tubule epithelial cells) monolayers showed that crystal-related cell damage is associated with an increased production of free radicals and cell death. These phenomena were related to oxalate concentration, whereas free radical scavenging and degrading enzymes such as catalase (CAT) and superoxide dismutase (SOD) provided strong protection from the injury $(52,53)$. In experiments with fresh rat urothelium, crystals formed at the site of the damaged superficial cells in a free radical-rich environment, whereas administration of antioxidants (mannitol or ascorbic acid) abolished crystal formation (54). Hyperoxaluria was also shown to induce the production of free radicals in rat kidneys in vivo (55); . This effect was most notable in the early stages of urolithiasis and was not uniformly distributed throughout the kidney, possibly because of the nonuniform generation of free radicals and distribution of antioxidants in the tissue (56). Similar changes in the tissue distribution of free radicals and antioxidant enzymes were also observed in the later stages of urolithiasis, which could be explained by the supporting action of the inflammatory response and low activity of antioxidant enzymes (57). After inducing chronic hyperoxaluria in rats by adding $0.75 \% \mathrm{EG}$ to drinking water, in addition to damaging cell membranes, the oxalate-driven enhanced production of free radicals impaired kidney function by decreasing renal blood flow and glomerular filtration rate. The damaging effects of oxalate were by pretreating animals with SOD, which proved the crucial role or free radicals in the initial phases of KSD (58). These data suggest that oxalate by itself could start the formation of kidney stones.

In summary, in animal kidneys, oxalate is capable of damaging the apical membrane of proximal tubule cells and impairing urine flow by decreasing kidney functions via promoting the production of free radicals. In human kidneys, however, the situation could be somewhat different. Limited studies have shown that markers of oxidative stress and renal cell injury did not increase even after an intense load with oxalate (22).

In the rat kidney cell line NRK52E, treatment with oxalate and crystals of $\mathrm{CaOx}$ monohydrate or brushite caused an elevated concentration of free radicals and increased mRNA and protein expression of monocyte chemoattractant protein 1 (MCP-1), a local mediator of inflammatory response. Pretreatment with catalase and diphenylene-iodium reduced the expression of MCP-1 by scavenging free radicals, thus suggesting that the initial upregulation of MCP-1 was rather a response to the accumulation of free radicals than to the accumulation of oxalate, brushite, or $\mathrm{CaOx}$ monohydrate (59-61). In studying the damaging effects of oxalate crystals on membrane integrity, various molecules were found to inhibit the binding of $\mathrm{CaOx}$ monohydrate to the cell surface. A variety of compounds (Table 1) were found to diminish the binding capacity of $\mathrm{CaOx}$ monohydrate crystals to BSC-1 (African green monkey kidney epithelial cells) or MDCK cell lines, thus preventing damage (62). 
Table 1 Compounds and conditions that affect the onset and severity of oxalate urolithiasis (Collected from the literature cited in the text)

\begin{tabular}{lll}
\hline $\begin{array}{l}\text { Compounds or } \\
\text { conditions }\end{array}$ & Promoters of urolithiasis & Inhibitors of urolithiasis \\
\hline $\begin{array}{l}\text { Oxalate precursors from } \\
\text { food }\end{array}$ & $\begin{array}{l}\text { glyoxylate, galactose, lactose, } \\
\text { tryptophan, phenylalanine, } \\
\text { tyrosine, creatinine, purines }\end{array}$ & \\
\hline Vitamins & vitamin C (oxalate precursor) & $\begin{array}{l}\text { vitamins A, C and E (scavengers of free radicals), } \\
\text { vitamin B6 }\end{array}$ \\
\hline Various compounds & $\begin{array}{l}\text { heparin, chondroitin sulfate, heparan sulfate, } \\
\text { hyaluronic acid, polyapartic acid, polyglutamic acid, } \\
\text { dextran sulfate, citrate }\end{array}$ \\
\hline $\begin{array}{l}\text { Specific proteins } \\
\text { crystal adhesion inhibitor protein, osteopontin, } \\
\text { nephrocalcin, Tamm-Horsfall protein, prothrombin } \\
\text { fragment 1 }\end{array}$ \\
\hline $\begin{array}{l}\text { Mediators of the } \\
\text { inflammatory response }\end{array}$ & $\begin{array}{l}\text { monocyte chemoattractant protein (a response to free } \\
\text { radicals) }\end{array}$ \\
\hline $\begin{array}{l}\text { Compounds affecting } \\
\text { free radicals }\end{array}$ & $\begin{array}{l}\text { calcium oxalate monohydrate } \\
\text { (promoters of free radicals) }\end{array}$ & $\begin{array}{l}\text { catalase, superoxide dismutase, manitol (free radical } \\
\text { scavengers) }\end{array}$ \\
\hline $\begin{array}{l}\text { Physical influences } \\
\text { trauma and membrane injury }\end{array}$ & & \begin{tabular}{l} 
Oxalobacter formigenes \\
\hline Microorganisms
\end{tabular} \\
\hline
\end{tabular}

Recently, the crystal adhesion inhibitor protein (CAI) was described. In the BSC-1 cell line, it blocked the adhesion of $\mathrm{CaOx}$ monohydrate to the cell surface. This protein was also detected in human urine (63). Furthermore, the glycoprotein osteopontin, which is found in urine, can inhibit all stages of the stoneforming process. In addition, osteopontin can also direct crystallisation toward the $\mathrm{CaOx}$ dihydrate rather than the $\mathrm{CaOx}$ monohydrate, which is of significance because in in vitro conditions, $50 \%$ more $\mathrm{CaOx}$ monohydrate is found attached to rat inner medullary collecting duct cells than $\mathrm{CaOx}$ dihydrate $(2,64)$. The expression of osteopontin increased in a dosedependent manner in rats treated with EG. In the control kidneys, osteopontin was expressed in the thin limbs of the loop of Henle and papillary surface epithelium; hyperoxaluria upregulated its expression, while the presence of $\mathrm{CaOx}$ crystals induced its expression in the entire nephron $(65,66)$. These data suggested that osteopontin may be one of the key in vivo protectors from oxalate stone formation. Other proteins, like nephrocalcin, prothrombin fragment 1 , and calgranulin, inhibited aggregation and crystallisation of oxalate complexes in urine, and may have prevented the initial steps in stone formation (2, 67). In healthy humans, Tamm-Horsfall protein exhibited the same effect as nephrocalcin and prothrombin fragment 1 . However, the Tamm-Horsfall protein obtained from recurrent stone formers did not modulate the rate of nucleation, while the aggregation of the crystals was even promoted and not inhibited (68). In addition to these specific proteins, urine proteins in general can be incorporated in the stone matrix dose-dependently, thus enhancing the degradation or dissolution of stones (69). Furthermore, some polypeptides can display similar effects on $\mathrm{CaOx}$ crystallisation. One is urinary bikunin, an integral part of the inter- $\alpha$-inhibitor (ITI) protein. The expression of bikunin mRNA and protein and the expression of ITI protein in rat kidneys showed a time-dependent increase following EG treatment $(70,71)$.

\section{Compounds and other factors that modulate urine oxalate concentration and urolithiasis}

Various compounds, pathophysiological conditions, and even intestinal bacterial flora are known to either promote or inhibit the onset and severity of oxalate urolithiasis. They are summarized in Table 1. Some vitamins are known to influence the incidence and severity of oxalate crystal formation in kidneys. Vitamin E, with its strong antioxidant properties was shown to prevent cyclosporine A-induced hyperoxaluria in rats (72). After long-term dietary administration, this vitamin also acted beneficially in aging kidneys of old male rats. The markers of lipid peroxidation were elevated and the vitamin E-enriched diet lowered 
these markers, increased glomerular filtration rate by $\sim 50 \%$, and returned the renal vascular resistance to the level found in young animals (73), thus indirectly proving the beneficial role of this vitamin in oxalate urolithiasis. Recent studies have provided a more focused correlation between the oxalate-induced production of free radicals and effects of vitamin E. In rats fed with a vitamin E-deficient diet accompanied by $\mathrm{EG}$ treatment, the formation of $\mathrm{CaOx}$ crystals intensified and their volume in urinary sediment increased causing atrophy and dilatation of tubules as well as interstitial cellular infiltration. The administration of vitamin $\mathrm{E}$ ameliorated these effects, most likely due to its anti-oxidative properties $(74,75)$.

Vitamin B6 deficiency increased the excretion of endogenous oxalate, which was further enhanced by adding glycine, deoxypyridoxine, and isonicotic acid hydrazide to the diet (76). Vitamin B6 was also helpful in reducing elevated concentrations of urine oxalate following ingestion of tryptophan (77). While vitamin E inhibited the formation of urinary stones via inhibiting the production of free radicals, it seems that vitamin B6 can affect metabolic pathways involved in the generation of oxalate. The deficiency of vitamin B6 strongly promoted an abundance of urine oxalate when the animals were treated with i.p. injections of glycolic acid, ethanolamine or EG but not glyoxylic acid, indicating that vitamin B6 could impact the metabolic pathways of oxalate production (78). However, vitamin B6 apparently has a role in lipid peroxidation as well. Rats fed with a vitamin B6deficient diet exhibited higher susceptibility of kidneys to lipid peroxidation and showed higher contents of lipid peroxide (79). This indicated that vitamin B6, besides inhibiting oxalate metabolism, can also protect kidneys from oxalate damaging effects by inhibiting the production of free radicals. A clinical study involving 85,000 female participants showed that vitamin B6 could indeed reduce oxalate urolithiasis, but only to a certain extent. The follow-up survey 14 years later revealed a lower incidence of oxalate urolithiasis in the group taking $>40 \mathrm{mg}$ vitamin B6 per day compared to the group taking $<3 \mathrm{mg}$ vitamin B6 per day (80). Vitamin B6, however, can in certain conditions be harmful. If the food contains an ample amount $(5.2 \%)$ of hydroxyproline, oxalate excretion will increase as the supplementary doses of vitamin B6 increase (81). This finding supports the observation of a higher incidence of stones in the meat-consuming individuals (19). A greater amount of consumed meat means more consumed collagen, in which hydroxyproline is one of the main components.
Vitamin A could also play a role in oxalate lithogenesis. After inducing oxalate urolithiasis, rats pretreated with vitamin A had smaller oxalate deposits in kidneys than controls. In contrast, after urolithiasis had already developed, later treatment with vitamin A had no beneficial effect (82).

However, not all vitamins follow a beneficial pattern in preventing oxalate urolithiasis. Vitamin C most likely has an adverse effect (83). Despite its numerous positive roles in the metabolism, vitamin C serves as an oxalate precursor because it is partially metabolized into oxalate. Increased urinary oxalate excretion was observed in humans that consumed $1000 \mathrm{mg}$ ascorbic acid per day (84). Similarly, the same study that reported a beneficial role for vitamin B6 in a large number of human participants failed to find any significant effect of vitamin $\mathrm{C}$ at doses from $250 \mathrm{mg}$ per day to $1500 \mathrm{mg}$ per day (80). Recent studies have suggested that a more individual approach should be taken in testing the consumption of vitamin $\mathrm{C}$ during oxalate urolithiasis, since the participants, being stone-formers or not, either did not respond to the treatment $(60 \%)$ or responded with an increased excretion of urinary oxalate (84). In contrast to the effect of vitamin $\mathrm{C}$, which is metabolised to oxalate, when used in an experimental model on living epithelium, vitamin $\mathrm{C}$ can abolish crystal formation in a free radical-rich environment, most likely due to its antioxidant properties (54).

Some sugars also influence oxalate metabolism at various levels of efficiency and intensity. Rats fed with galactose and lactose showed a higher concentration of endogenous oxalate in their urine than rats fed with sucrose, fructose or glucose. Although the metabolism of both glucose and galactose eventually intersects at glycolaldehyde, an intermediary compound in the metabolic production of oxalate, galactose metabolism largely takes a different route, via galactonic acid formation (85).

Citrate is known to have certain influence on the formation of oxalate kidney stones. The urine of stoneformers contains significantly less citrate than that of stone non-formers. Furthermore, urine in males has significantly less citrate in comparsion to females (86, 87). Hypocitraturia due to malabsorption or other reasons may be one of the predisposing factors for crystallization and urolithiasis $(88,89)$. Citrate apparently inhibits saturation, crystallisation, and further growth of already formed $\mathrm{CaOx}$ and $\mathrm{CaP}$ crystals $(90,91)$. Furthermore, citrate can promote inhibitory activity in the Tamm-Horsfall protein from 
healthy individuals or even reverse the protective actions of this protein in stone formers (68). Various compounds that inhibit or promote the formation of oxalate stones are listed in Table 1.

\section{Oxalate-handling transporters and their role in hyperoxaluria and KSD}

The Slc26 family of multifunctional anion exchanger proteins is believed to handle oxalate in mammalian organs (92-95) and a few specific members of this family may play a key role in the aetiology of hyperoxaluria and oxalate urolithiasis. Three organs, the intestine as an absorbing organ, liver as a metabolic organ, and kidneys as the main secretory organ, are major players in handling oxalate in the organism. Each has one or more relevant transporter from the Slc26 family expressed in the epithelial cell membrane that contributes to the transmembrane movement of oxalate. The thus far defined and more or less functionally characterized transporters and their organ localization are listed in Table 2.

During intestinal absorption, oxalate in food can cross the intestinal wall paracellularly and/or transcellularly. The paracellular flux occurs through simple diffusion; dependent on the oxalate gradient orientation, this process can function in both directions: from lumen to blood or from blood to lumen. However, in vivo models are always more complex since the concentration and electrical (electrochemical) gradients are permanently present, whereas the paracellular path is more or less limited. The transcellular path is mediated by specific transporters which are located in the epithelial cell membranes (92). Oxalate absorption in the human intestine starts very soon after ingestion. The rise in excretion by the kidneys is evident as soon as $20 \mathrm{~min}$ after oxalate ingestion and has two distinct peaks, at $40 \mathrm{~min}$ and 180 min after ingestion (13). Since the gastro-ileal passing time in healthy humans is approximately $10 \mathrm{~h}$, it can be concluded that absorption starts in the stomach and reaches its maximum in the small intestine $(13,20)$. A few studies have shown that the stomach could be an important locus of oxalate absorption. The first peak of oxalate absorption could not be recorded in patients with a gastrectomy (12, 13, 93). Due to the tight epithelium, oxalate transport in the stomach is most likely transcellular (93). Immunocytochemical findings of the presence of an oxalate transporter, sulfate anion $\left(\mathrm{SO}_{4}^{2-}\right)$ transporter Sat-1 (Slc26a1), in the oxyntic cells of the rat stomachs support claims in favour of this type of transport. However, the staining was not found in the cell membrane, but rather in certain intracellular, nonendosomal organelles (96). In the mouse stomach, in addition to Sat-1, another oxalate transporter, chloride/ formate exchanger CFEX (Slc26a6), was demonstrated

Table 2 Transporters that contribute to oxalate handling in the organism

\begin{tabular}{|c|c|c|c|c|}
\hline Name & Alias & Species & Organ expression & Substrates \\
\hline SLC26A1 & SAT-1 & $\begin{array}{l}\text { rat, mouse, } \\
\text { human }\end{array}$ & $\begin{array}{l}\text { kidney, liver, } \\
\text { cecum, heart, brain, muscle }\end{array}$ & $\begin{array}{l}\text { sulfate, oxalate, } \\
\text { bicarbonate, glyoxylate }\end{array}$ \\
\hline SLC26A2 & DTDST & $\begin{array}{l}\text { rat, mouse, } \\
\text { human }\end{array}$ & $\begin{array}{l}\text { Duodenum, jejunum, ileum, } \\
\text { colon, kidney }\end{array}$ & oxalate \\
\hline SLC26A3 & DRA & $\begin{array}{l}\text { rat, mouse, } \\
\text { rabbit, human }\end{array}$ & $\begin{array}{l}\text { duodenum, jejunum, ileum, } \\
\text { cecum }\end{array}$ & $\begin{array}{l}\text { sulfate, oxalate, } \\
\text { bicarbonate, chloride }\end{array}$ \\
\hline SLC26A6 & CFEX/PAT-1 & mouse, human & $\begin{array}{l}\text { kidney, pancreas, } \\
\text { duodenum, jejunum, ileum, } \\
\text { colon, heart, } \\
\text { muscle, placenta }\end{array}$ & $\begin{array}{l}\text { sulfate, oxalate, } \\
\text { bicarbonate, chloride, formate, } \\
\text { hydroxyl-ion }\end{array}$ \\
\hline SLC26A7 & - & Human & $\begin{array}{l}\text { stomach, kidney, } \\
\text { placenta, testis }\end{array}$ & $\begin{array}{l}\text { sulfate, oxalate, } \\
\text { chloride }\end{array}$ \\
\hline SLC26A8 & TAT-1 & Human & kidney, testis & $\begin{array}{l}\text { sulfate, oxalate, } \\
\text { chloride }\end{array}$ \\
\hline SLC26A9 & - & Human & $\begin{array}{l}\text { lungs, stomach, } \\
\text { kidney }\end{array}$ & $\begin{array}{l}\text { chloride, bicarbonate, hydroxyl-ion } \\
\text { oxalate? }\end{array}$ \\
\hline
\end{tabular}

SAT-1, Sulfate anion transporter-1; DTDST, Diastrophic dysplasia sulfate transporter; DRA, Down regulated in adenoma; CFEX, Chloride/formate exchanger; PAT-1, Putative anion transporter 1; TAT-1, Testis anion transporter 1. Data collected from the literature $(91,95,96,97,100,112,116,121,123,128,153$, and 188). 


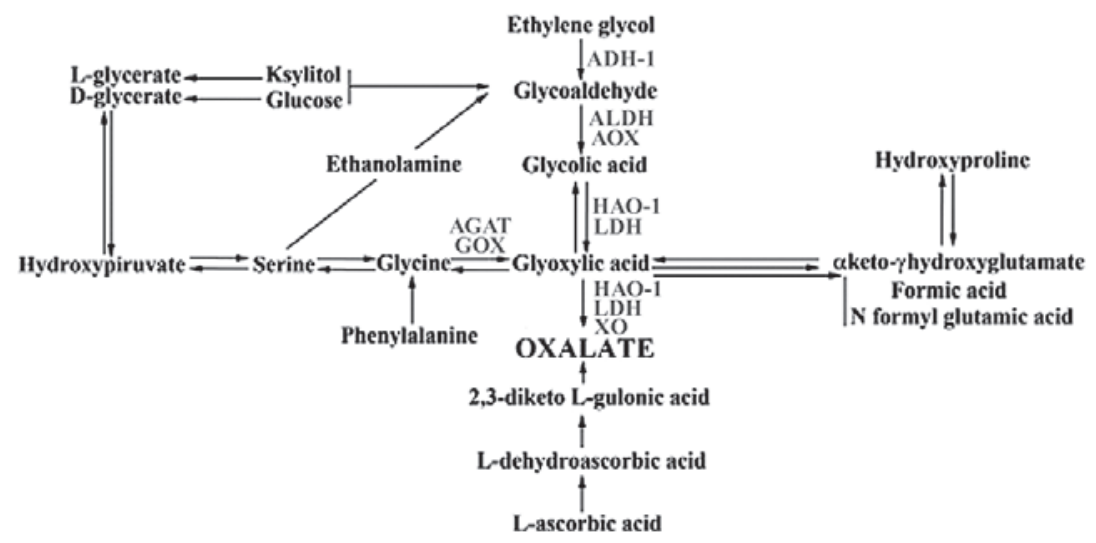

Figure 2 Oxalate-related metabolic pathways. Metabolic pathways and critical enzymes that catalyze the respective steps in conversion of various precursors to oxalate are shown. ADH-1, alcohol dehydrogenase 1; ALDH, aldehyde dehydrogenase; $A O X$, aldehyde oxidase; $L D H$, lactate dehydrogense; $X O$, xantine oxidase; $G O X$, glycine oxidase; $A G A T$, alanine glyoxylate aminotransferase; HAO-1, hydroxyacid oxidase 1. Modified from $(11,14)$.

in parietal cells at the level of both mRNA $(97,98)$ and protein, but once more in an intracellular compartment (99). Thus, the only plausible transporter that may facilitate oxalate transport across the stomach epithelium could be the $\mathrm{SO}_{4}{ }^{2-} / \mathrm{Cl} /$ oxalate exchanger Slc26a7. In the mouse stomach, this transporter has been localized to the parietal cell basolateral membrane (100).

Although earlier studies indicated that oxalate absorption occurs in the initial parts of the gastrointestinal tract $(13,20)$, patients who developed hyperoxaluria following a jejuno-ileal bypass exhibited major absorption in the colon (101), thus indicating that, at least in certain conditions, oxalate can also be absorbed in the distal parts of the intestine. Evidence for transcellular absorption of oxalate in the intestine with regard to other anions came from observations that oxalate and $\mathrm{Cl}^{-}$share a common anion transport system in the rabbit ileum and colon, which was inhibited by the stilbene derivatives SITS and DIDS $(102,103)$. In the rabbit colon, which is an important site for oxalate uptake and/or excretion, oxalate transport is mediated by $\mathrm{Na}^{+}-, \mathrm{Cl}^{-}$, and $\mathrm{HCO}_{3}^{-}-$ dependent pathways $(104,105)$. In mice, a DIDSsensitive $\mathrm{Cl}^{-} / \mathrm{HCO}_{3}^{-}$exchanger was identified as the $\mathrm{Cl} /$ formate exchanger CFEX [putative anion transporter 1 (PAT-1); Slc26a6], which can also can function as an oxalate/formate exchanger with higher affinity for oxalate than for formate $(97,98)$. A strong expression of Slc26a6 mRNA was detected in mouse duodenum, jejunum, and ileum, while the cecum and colon showed only a slight expression (97). Comparable findings were obtained by Western blotting and immunohistochemistry in the mouse duodenum, where the apical region of the absorptive cells was stained positive for Slc26a6. The importance of Slc26a6 was supported by the data from knock-out (KO) mice lacking the coding gene for CFEX, which exhibited a strongly diminished oxalate transport in both intestine and kidneys (106-109). These studies further revealed that ileal oxalate transport in wild type (WT) mice was mainly secretory, whereas in CFEX KO mice, this transport shifted towards absorption, indicating that the usual function of CFEX in the intestine is mainly secretory. Furthermore, following addition of DIDS, ileal oxalate secretion in WT mice switched to oxalate absorption, while in KO mice, DIDS had no significant effect, indicating that the oxalate absorption pathway in the intestine was not mediated by a DIDS-sensitive process (107). These data are in accordance with earlier results in rats and rabbits, which showed that the small intestine is mainly an oxalate secretory organ with high CFEX expression, while the colon is predominantly an oxalate absorptive organ $(110,111)$ with low CFEX expression. In addition to CFEX, other members of the Slc26 family are localized in the intestine. Sat-1 (Slc26a1) is usually associated with kidneys and liver, but recently its mRNA expression was also detected in mouse cecum (112) and human small intestine and colon (113). However, although it is presumed that Sat-1 is localized in the BLM of intestinal epithelial cells $(114,115)$, in rats an anti-Sat- 1 antibody clearly labeled the Sat-1 protein in specific membrane domains of hepatocytes and proximal tubules (116-118), whereas in the intestine, the same antibody stained intracellular organelles, possibly mitochondria, with 
the following pattern of staining intensity: duodenum $<$ jejunum $<$ ileum $<$ colon $(96,119)$. Furthermore, a recent study on mouse duodenum by Ko et al. (120) questioned the role of Sat-1 in transporting oxalate, since the active oxalate secretion in this intestinal segment was not reduced in Sat1 KO mice.

Another transporter from the same family is the protein known as "Down-Regulated in Adenoma" [DRA (SLC26A3)/Dra (Slc26a3)], which mediates $\mathrm{Na}^{+}$-independent $\mathrm{SO}_{4}^{2-}$ and oxalate uptake in mouse intestine (121). In transfected Sf9 insect cells (originate from insect ovarian tissue), human DRA mediated the DIDS-sensitive uptake of $\mathrm{SO}_{4}^{2-}$ and oxalate (122). In mice, Dra mRNA was only slightly expressed in the small intestine and strongly in the cecum and proximal colon, while in other organs the expression was below detection limits (121). Except for mediating $\mathrm{SO}_{4}^{2-}$ and oxalate uptake, DRA appears to be a generally versatile anion exchanger capable of mediating $\mathrm{Cl}^{-} / \mathrm{Cl}^{-}, \mathrm{HCO}_{3}^{-}$ $\mathrm{Cl}^{-}$, and $\mathrm{Cl}^{-} / \mathrm{SO}_{4}{ }^{2-}$ exchange in rats, rabbits, and humans with a high affinity for $\mathrm{Cl}^{-}(123)$. DRA exhibits much lower rates of oxalate transport than other members of the Slc26 family (92). However, DRA KO mice exhibited significantly reduced mucosa-to-serosa oxalate flux in ileum and colon when compared to WT mice $(114,115)$. Deletion of the Slc23a3 gene in addition to previously described disturbances in oxalate transport $(114,115)$ caused diarrhea and an increased expression of other ion exchangers in the intestine, including the sodium-proton exchanger 3 (NHE3; SLC9A3), H,K-ATPase (EC 3.6.3.10), and the amiloride-sensitive epithelial sodium channel $(\mathrm{ENaC})$ for compensation (124). Mutations of the gene encoding DRA cause congenital $\mathrm{Cl}^{-}$diarrhea in humans (125). DRA may indirectly take part in oxalate urolithiasis by participating in $\mathrm{Cl}^{-}$uptake, which is an essential anion for oxalate extrusion via CFEX (vide infra).

Very little is known about the expression and function of the Diastrophic Dysplasia $\underline{\text { Sulfate }}$ Transporter (DTDST; SLC26A2/Slc26a2). Evidence suggests that this transporter should be expressed in the epithelial cell apical membrane of the human small and large intestine $(114,115,126)$, but thus far its presence at the level of mRNA has been proven only in the rat intestine (114). The affinity of DTDST for oxalate and its role in handling them still need confirmation, but recent findings suggest that this transporter could be responsible for the residual intestinal secretion of oxalate in CFEX KO mice (115, $127,128)$. The localization of various members of the Slc26 family along the mammalian intestine is depicted in Fig. 3.

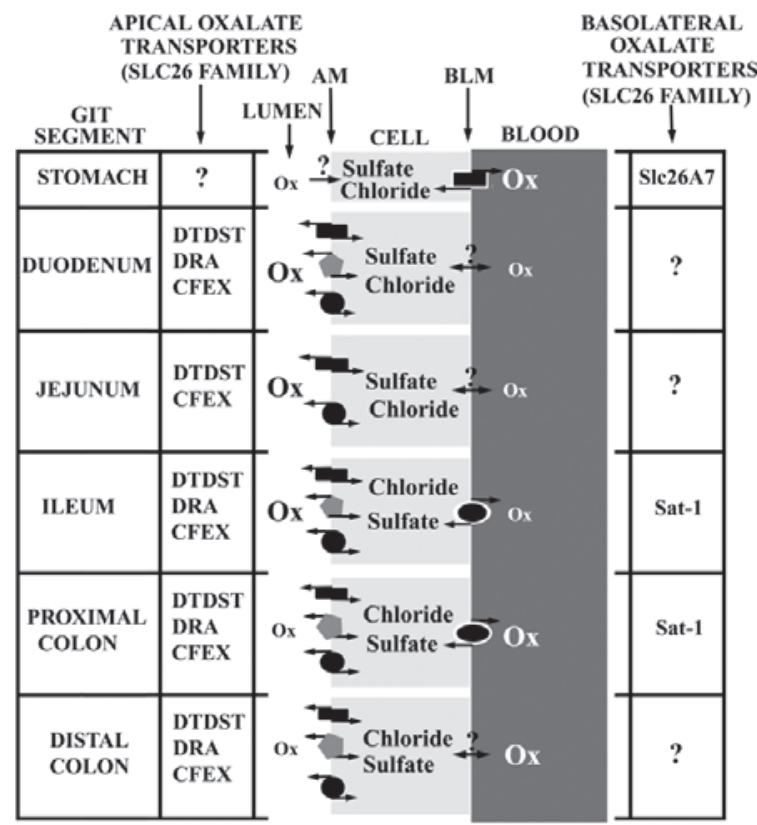

Figure 3 Transporters along the rodent gastrointestinal tract involved in oxalate handling. The localization of the thus far detected oxalate transporters in the apical (luminal, AM) and basolateral (contraluminal, BLM) membranes in various segments of the mammalian gastrointestinal tract (GIT) are shown. Unknown mechanisms are indicated by a question mark (?). Various intestinal segments exhibit various modes of transporter expression in the apical membrane resulting in different oxalate trafficking; duodenum, jejunum, and ileum are the segments with high oxalate secretion due to relatively higher CFEX (Slc26a6) then DRA (Slc26a3) expression (107, 110, 111). The opposite expression pattern of these two transporters (DRA $>C F E X)$ in proximal and distal colon points to the absorptive role of the colon in oxalate trafficking $(114,115,121)$. In contrast, the expression of DTDST (Slc26a2) is similar in all intestinal segments and most likely contributes to very small amount of oxalate excretion $(127,128)$. In addition to sulphate, all of the described transporters in the apical and basolateral membrane (Sat-1/Slc26al) can utilize $\mathrm{Cl}, \mathrm{HCO}_{3}^{-}$or $\mathrm{OH}^{-}$as substrates, depending on availability and affinity.

As for oxalate transport in the liver, its definition is not as vague as in the intestine. Haepatocytes are a major site of oxalate production in the organism. As a metabolic end-product, oxalate is removed from hepatocytes before it is excreted from the organism, largely via the kidneys and to minor extent via the intestine. The localization of oxalate transporters in hepatocytes and kidneys is depicted in Fig. 4. Hepatocytes utilize substantial $\mathrm{SO}_{4}{ }^{2-}$ in various detoxification and sulfation reactions. The $\mathrm{SO}_{4}{ }^{2-} /$ anion exchange system that transports various anions including oxalate was demonstrated in the sinusoidal 
membrane of rat hepatocytes (129). In support of these findings, Sat-1, an exchanger of $\mathrm{SO}_{4}{ }^{2-}$ and an oxalate, was localized in rats to the hepatocyte sinusoidal membrane $(116,117,130)$. Recent transport studies on Sat-1 expressing oocytes demonstrated that Sat-1 can exchange $\mathrm{SO}_{4}^{2-}$ or $\mathrm{HCO}_{3}^{-}$for oxalate in both directions, but the affinity for oxalate is lower than for counter anions. However, due to high intracellular concentrations of oxalate, the exchanger most probably operates as an oxalate extruder in exchange for extracellular $\mathrm{SO}_{4}^{2-}$ or $\mathrm{HCO}_{3}^{-}$(131). A limited amount of oxalate may be excreted into bile, possibly via CFEX in the bile canalicular membrane, but the counter anions are unknown. Our unpublished immunocytochemical data with an available commercial polyclonal antibody have indicated the presence of the CFEX protein in this membrane (Fig. 4), but this finding awaits confirmation with different antibodies by other research groups.

The Slc26 family of anion transporters is also responsible for handling oxalate and related anions in kidneys. These transporters, located in the apical as well as in the BLM of epithelial cells (Fig. 4), primarily exchange oxalate for formate $\mathrm{HCOO}^{-}$or $\mathrm{Cl}^{-}$. This way, they also participate in the reabsorption of $\mathrm{Cl}^{-}$and $\mathrm{Na}^{+}$ from the glomerular filtrate (92). As demonstrated in dogs (132), humans (133), sheep (134), and rats (135), the bulk of body oxalate is excreted by kidneys, partially via glomerular filtration and partially via active secretion in the proximal parts of the nephron. In addition to secreting oxalate, proximal tubules are also sites of limited oxalate reabsorption $(135,136)$, whereas the distal parts of a nephron are not involved in oxalate transport (137). Detailed studies on rat kidney proximal tubules indicated the presence of a low-affinity, high-capacity excretory system for oxalate, which can be inhibited by $p$ chloromercuribenzoic acid (PCMB), cyanide, indacrinone (MK-196), furosemide, and $p$ aminohippurate $(\mathrm{PAH})(137,138)$. However, these and other studies suggested that more than one secretory system, with different affinities for oxalate, may be responsible for oxalate handling in mammalian kidneys $(129,137$, and 138). The studies of oxalate transport in rabbit kidneys indicated proximal tubules as the main locus of net oxalate secretion, with the $\mathrm{S} 1 / \mathrm{S} 2$ and $\mathrm{S} 3$ segments having a dominant and minor role, respectively (139). Subsequent experiments linked the $\mathrm{Na}^{+}$-independent transport of $\mathrm{SO}_{4}^{2-}$ and $\mathrm{HCO}_{3}$-in the proximal tubule cell BLM $(140,141)$ to oxalate, according to which one oxalate is exchanged for one $\mathrm{SO}_{4}^{2-}$ or two $\mathrm{HCO}_{3}^{-}(142)$. A transporter with similar properties was finally cloned from rat liver. cDNA encoded for the $\sim 75 \mathrm{kDa} \mathrm{SO}{ }_{4}^{2-}$ transporter, Sat-1 (130). The expression of rat renal sulfate transport systems in $X$. laevis oocytes proved that Sat-1 mediated $\mathrm{Na}^{+}$-independent $\mathrm{SO}_{4}{ }^{2-}$ transport in the proximal tubule BLM (143). Further characterization showed that the basolateral Sat-1 can exchange extracellular oxalate for intracellular $\mathrm{SO}_{4}{ }^{2-}$ or $\mathrm{HCO}_{3}$, where $\mathrm{HCO}_{3}{ }^{-}$is constantly recycled across the BLM by a $\mathrm{HCO}_{3}^{-} / \mathrm{Cl}^{-}$exchanger (144). As shown in Fig. 4, in rat kidneys the Sat-1 protein was localized by immunochemical methods to the proximal tubule $\operatorname{BLM}(117,118)$.

Early studies on oxalate transport in rabbit kidney $\mathrm{BBM}$ indicated the presence of two distinct $\mathrm{Cl}^{-} /$ formate exchange systems. One was electroneutral, readily accepting $\mathrm{Cl}^{-}$and formate as substrates, without or with little affinity for oxalate, and was strongly inhibited by furosemide and not as strongly by DIDS. The second electrogenic accepted oxalate, $\mathrm{Cl}^{-}$, and formate with high affinity, and these anions were more strongly inhibited by DIDS than by furosemide $(145,146)$. Evidence for oxalate transport across both cell membrane domains came from in vitro experiments with LLC-PK1 cells. In this experimental model, oxalate secretion was presented by a two step process; the uptake of oxalate occured in exchange for $\mathrm{SO}_{4}^{2-}$ or $\mathrm{HCO}_{3}^{-}$across the proximal tubule cell BLM, followed by a release of oxalate in exchange for $\mathrm{SO}_{4}{ }^{2-}$ or $\mathrm{Cl}^{-}$across the $\mathrm{BBM}$ (147). In rabbit renal BBM, both $\mathrm{Na}^{+}$-dependent and $\mathrm{Na}^{+}$-independent modes of oxalate transport were demonstrated, whereas the $\mathrm{Na}^{+}$-driven mode was almost negligible (148). These functional data of $\mathrm{Na}^{+}$-independent oxalate transport in the BBM were ultimately linked to CFEX. Mouse CFEX was cloned, found to mediate DIDS-sensitive $\mathrm{Cl} /$ /formate exchange (149), verified as an ortholog of the human SLC26A6/putative anion transporter 1 (PAT-1), and immunochemically localized to the proximal tubule $\operatorname{BBM}(98,99)$. Mouse CFEX was also shown to mediate the exchange of various anions $\left(\mathrm{Cl}^{-}\right.$, formate, oxalate, $\mathrm{HCO}_{3}^{-}, \mathrm{OH}^{-}$, and $\mathrm{SO}_{4}^{2-}$ ) (150). Under optimal conditions (transport surveys under equal substrate concentrations), the oxalate uptake was more than 2-fold higher than the uptake of other substrates, indicating a higher affinity for oxalate. $\mathrm{Cl}^{-}$seems to be the major anion in exchange with other anions, and this fact may play an important role in the aetiology of oxalate stones in kidneys, since $\mathrm{Cl}^{-}$is the crucial anion for CFEX- 


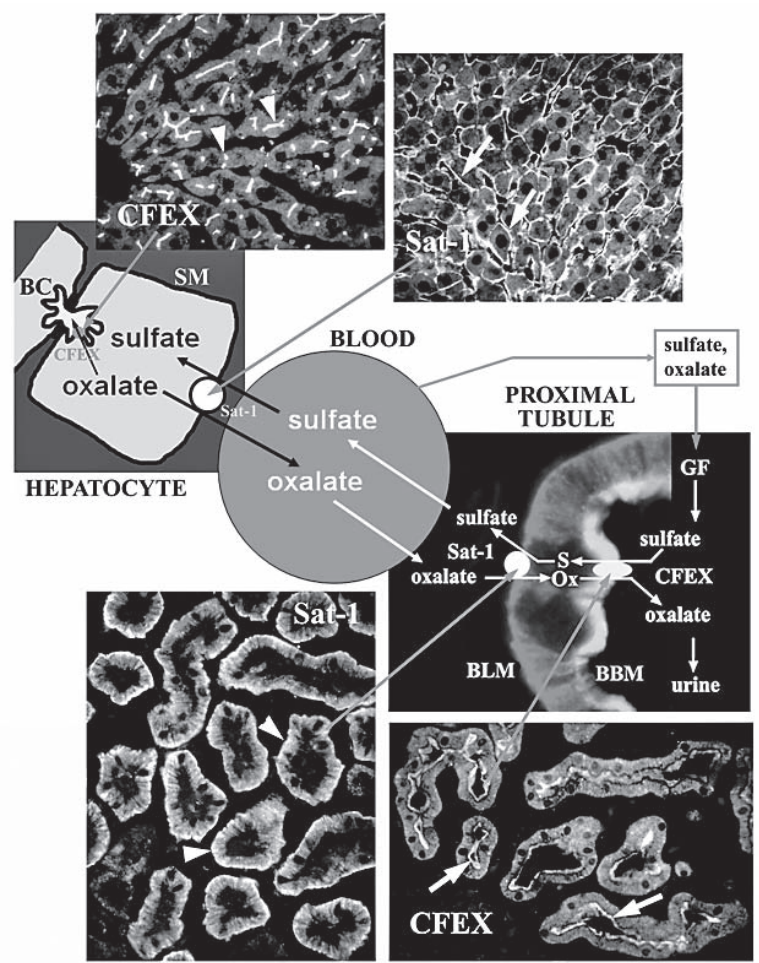

Figure 4 Oxalate transporters in hepatocytes and renal proximal tubule cells. In physiological conditions, oxalate is largely produced in hepatocytes, released in blood, and excreted in kidneys by glomerular filtration $(G F)$ and secretion in proximal tubules. In hepatocytes, oxalate is eliminated partially (unknown proportion) by the CFEX-mediated secretion in bile (counterion unknown), and largely in exchange for sulfate by the Sat-1-mediated transport into blood. As shown in immunocytochemical images, in the rat liver the CFEX protein (arrowheads) is localised to the bile canalicular membrane (our unpublished data), whereas the Sat-1 protein (arrows) is localized to the sinusoidal membrane $(116,117)$. In the renal proximal tubule cells, the process of oxalate $(O x)$ secretion starts with the basolateral Sat-1-mediated uptake of oxalate in exchange for reabsorbed sulphate (or $\mathrm{Cl}$, or $\mathrm{HCO}_{3}^{-}$), and finishes with the apical CFEX-mediated extrusion of oxalate into the tubule lumen in exchange for sulphate (or $\mathrm{Cl}$, or $\mathrm{HCO}_{3}^{-}$). As shown in immunocytochemical images, in the rat proximal tubule cells the Sat-1 protein (arrowheads) is localised to the basolateral membrane $(117,118)$, whereas the CFEX protein (arrows) is localised to the apical (brush-border) membrane (our unpublished data).

mediated $\mathrm{Cl}$ \%oxalate exchange in the BBM. Oxalate secretion in the proximal tubule cell starts with $\mathrm{Na}^{+}-$ $\mathrm{SO}_{4}^{2-}$ co-transport, mediated by the apical $\mathrm{NaSi}-1$ (SLC13A1), which creates an outward $\mathrm{SO}_{4}{ }^{2-}$ gradient that drives Sat-1-mediated $\mathrm{SO}_{4}{ }^{2-}$ oxalate exchange across the BLM. The internalized oxalate generates an outward gradient, which drives the CFEX-mediated, oxalate/ $\mathrm{SO}_{4}{ }^{2-}\left(\mathrm{Cl}^{-}, \mathrm{HCO}_{3}^{-}\right)$exchange across the BBM.
A part of the secreted oxalate can recycle back into the cell by CFEX-mediated $\mathrm{Cl}$ \%oxalate exchange (151, 152). Thus, in the proximal tubules of healthy animals, CFEX regulates urine oxalate secretion by continuous recycling and partial removal from tubular fluid. In CFEX KO mice, urine oxalate is $\sim 4$-fold higher than in wild type mice, but this is at least partially a consequence of the absence of CFEX-mediated intestinal excretion and increased ileal absorption of oxalate, followed by increased renal excretion via glomerular filtration and transporter-mediated secretion $(107,108)$. In rats, renal Sat-1 has low affinity for oxalate when compared to $\mathrm{SO}_{4}{ }^{2-}$ or $\mathrm{HCO}_{3}^{-}$, and in physiological conditions it may only transport insignificant amounts of oxalate. In hyperoxalemia (high plasma concentration of oxalate), however, Sat-1-mediated oxalate transport may rise significantly (131). Although Sat-1 exhibits low affinity for oxalate, its importance was demonstrated in Sat-1 KO mice, which exhibited hyperoxalemia (due to decreased intestinal excretion), hyperoxaluria (due to increased glomerular filtration of oxalate), and urolithiasis [reviewed in (153)]. However, in spite of numerous collected data regarding the renal handling of oxalate, the overall oxalate transport in kidneys is still a question issue of debate. Up to $95 \%$ of oxalate in a healthy organism is excreted via kidneys, while the rest is lost through intestinal excretion. In some pathological conditions, such as chronic renal failure (CRF) due to inflammatory processes, glomerulosclerosis, and fibrosis, this pattern tends to shift in favour of intestinal excretion $(91,154)$. In such cases, the intestine take over a part of the kidney's role in oxalate excretion, and $28 \%$ to $50 \%$ of oxalate can be excreted through this organ $(110,155)$. However, different parts of the intestine play different roles in oxalate handling. In healthy rabbits and rats, the small intestine exhibited an oxalate secretory flux and the colon was the main site of oxalate absorption (111), whereas in experimental CRF, no change in oxalate trafficking was observed in the small intestine, but a significant decrease of oxalate absorption and increase of its excretion was detected in the colon (105). The renal handling of oxalate in this pathophysiological condition due to a reduced filtration rate and active secretion also seems to be impaired. During CRF, the expression of renal Sat-1 is significantly reduced, which means that the active excretion of oxalate via the proximal tubule is also impaired. In addition, $\mathrm{NaS}-1$, an important supplier of intracellular $\mathrm{SO}_{4}{ }^{2-}$ for Sat-1-mediated oxalate transport, is also downregulated (156) (Figure 5.). 


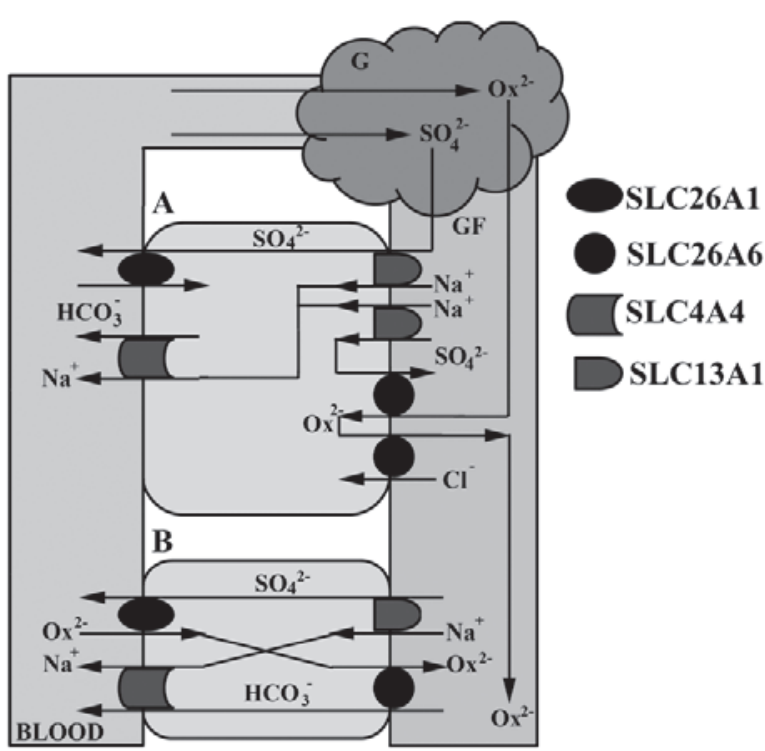

Figure 5. A schematic presentation of ion transport(er)s in the basolateral (BLM) and apical (AM) membranes of kidney proximal tubules (PT). A. In physiological conditions, oxalate $\left(\mathrm{Ox}^{2-}\right)$ and sulfate $\left(\mathrm{SO}_{4}^{2-}\right)$ from blood are passively filtered in glomeruli $(G)$ into glomerular filtrate (GF). $\mathrm{SO}_{4}^{2-}$ and $\mathrm{Na}^{+}$are actively reabsorbed from the glomerular filtrate by SLC13A1 in the AM and returned to blood by the basolateral transporters SLC26A1 and SLC4A4 in exchange for $\mathrm{HCO}_{3}^{-}$. A minor part of the reabsorbed $\mathrm{SO}_{4}^{2-}$ is used by the apical transporter SLC26A6 as a substrate in exchange for oxalate, which is then excreted in exchange for $\mathrm{Cl}$. Oxalate used in this way is finally eliminated from the body via urine. B. In case of hyperoxalemia, the oxalate transport changes; the excess oxalate is actively eliminated in co-ordinative actions of the basolateral SLC26A1 and apical $\mathrm{SLC} 26 \mathrm{A6}$ in exchange for $\mathrm{SO}_{4}^{2-}, \mathrm{Cl}, \mathrm{HCO}_{3}^{-}$, or $\mathrm{OH}^{-}$, depending on affinity and/or concentration.

Further experimental evidence suggests that the SLC26 family of transporters is not the only one responsible for hyperoxaluria and formation of oxalate kidney stones. The members of several other families may also contribute by transporting a variety of compounds that affect oxalate crystallisation or other steps in stone formation (Table 2). One of them is the sodium-phosphate cotransporter IIa (NaPi-IIa), a member of the transporter family SLC34 (SLC34A1/ Slc34a1). NaPi IIa KO mice developed hypercalciuria and deposited both $\mathrm{CaP}$ and $\mathrm{CaOx}$ crystals in their kidneys in contrast to WT mice, and these data stressed that crystallisation occured when hyperoxaluria was linked to high $\mathrm{Ca}^{2+}$ concentrations (157). However, $\mathrm{CaP}$ deposits can form separately from $\mathrm{CaOx}$ deposits (158). This indicates $\mathrm{CaP}$ deposits are not required for the crystallisation and deposition of $\mathrm{CaOx}$, as had been indicated in certain in vitro experiments (158) and in vivo monitoring of stone-forming patients (159). Although it is likely that $\mathrm{CaOx}$ crystals can form over $\mathrm{CaP}$ plaques, especially if they are formed on a suitable position along the nephron, $\mathrm{CaP}$ plaques are not necessary for stone formation since patients that underwent an obesity-related bypass procedure formed $\mathrm{CaOx}$ stones without having $\mathrm{CaP}$ plaques (157, 159).

Another transporter indirectly tied to oxalate urolithiasis is a cotransporter of $\mathrm{Na}^{+}$and dicarboxylate 1 (NaDC-1). It is a member of the SLC13 (SLC13A2 in humans/Slc13a2 in rodents) transporter family, which is localised to the proximal tubule BBM and mediates the co-transport (reabsorption) of $\mathrm{Na}^{+}$and citrate from the ultrafiltrate. In rats treated with EG, protein and mRNA expression of $\mathrm{NaDC}-1$ were significantly increased and associated with lower urinary citrate. Treatment with potassium citrate exhibited an opposite effect; it reduced the expression of NaDC-1 protein and mRNA and increased urinary citrate (160). Thus, EG treatment lowered urinary citrate by upregulating its transporter and reabsorption, which may have affected (enhanced) the rate of oxalate crystallisation.

Sex and species differences, effects of hormones and heavy metals on oxalate levels, oxalate transporters, and incidence of oxalate nephrolithiasis

Over the years, many studies have reported on the presence of sex differences in the incidence of oxalate kidney stones and possible role of sex hormones and other factors in the aetiology of oxalate urolithiasis. The frequency of $\mathrm{CaOx}$ urolithiasis in the middle aged population is 2 to 3 times higher in men than in women, whereas in the young and elderly population, this male-dominant prevalence is absent (161-163). The male-dominant urolithiasis was initially associated with greater body mass and body surface area, which are positively correlated with higher rates of urine oxalate, $\mathrm{Ca}^{2+}$, and $\mathrm{Mg}^{2+}$ excretion $(35,164)$. However, in later studies the incidence of uric acid, but not $\mathrm{CaOx}$ stones, was associated with obesity (165). The higher incidence of urolithiasis in men can be related to mutations in X-linked genes, such as X-linked recessive hypophosphatemic rickets and Dent's disease, where male haemizygotes exhibit hypercalciuria and nephrocalcinosis (2). However, these mutations are not responsible for urolithiasis in idiopathic cases. Experimentally, sex differences in oxalate urolithiasis were clearly demonstrated in rats treated with EG, where testosterone promoted and 
estrogens inhibited the formation of oxalate stones (166). In rats, sex-related differences were evident already at the level of oxalate production in the liver, but these differences became evident only when the animals ingested the oxalate precursor EG, while under physiological conditions the urinary oxalate secretion was unaffected by androgens (167). Furthermore, the male-dominant incidence of urolithiasis may be related to the activity/expression of rate-limiting enzymes that contribute to oxalate synthesis in the respective organs, e.g., alcohol dehydrogenase 1 (ADH-1/Adh-1; EC 1.1.1.1), which catalyzes the conversion of EG to glycoaldehyde, and hydroxyacid oxidase (HAO-1/Hao-1, EC 1.1.3.15), which converts glycolate to glyoxylate. Thus, in both rat kidneys $(168,169)$ and liver $(170-172)$ the Adh-1 activity and its mRNA expression were found to be female-dominant due to stimulation by estrogens, whereas Hao-1 activity and its mRNA expression in rat liver and kidneys were found to be maledominant due to stimulation by androgens and inhibition by estrogens $(167,173,174)$. Although the enzymatic level suggests that oxalate metabolism is largely controlled by androgens, ovariectomized and EG-treated female rats showed significantly higher urinary oxalate excretion, $\mathrm{Ca}^{2+}$ content and crystal deposition, and a higher expression of osteopontin mRNA in the kidneys, suggesting that female sex hormones may also affect the deposition of renal crystals on several levels (175).

The sex-related oxalate metabolism, urine oxalate excretion, and the rate of stone formation may be connected with the expression of specific transporters responsible for oxalate transport. Previous microarray studies in rat organs exhibited limited male-dominant sex differences in the expression of Sat-1 mRNA in the kidney cortex but not in the liver (176). However, real time RT-PCR data in the rat liver and kidney tissues showed an absence of significant sex differences in Sat-1 mRNA expression, while Sat-1 protein expression and its activity, shown by Western blotting, immunocytochemistry, and transport studies in the same organs, were male-dominant, indicating a posttranscriptional regulation for this transporter. Additional experiments showed that, at least in the rat kidneys, the male-dominant sex differences in Sat-1 protein expression were driven by the inhibitory effects of estrogens and progesterone (117). In mice, sex hormones may also influence the expression of DRA in the large intestine; the expression of DRA mRNA in the colon of adult animals was 134-fold higher than in prepubertal mice, possibly due to the up-regulating effects of sex hormones after the onset of puberty (121). Apart from the liver and kidneys, sex hormones can also affect oxalate trafficking across the red blood cell membrane (RBC), which is most likely mediated by the anion exchanger AE3 (band 3; SLC4A3) (177, 178), with possible indirect consequences on stone formation in the affected individuals. A higher incidence of idiopathic nephrolithiasis was observed in male patients with abnormal oxalate transport in RBC (179).

The above mentioned data suggested a more direct impact of sex hormones on oxalate urolithiasis via oxalate metabolism and/or transport. However, the role of sex hormones may be indirect, by affecting the levels of citrate and scavengers of ROS, whose beneficial effects on stone formation have been discussed earlier. Female urine has a higher amount of citrate compared to that in males, and female sex hormones exhibit a clear regulatory role in citrate excretion. That is why ovariectomy in rats reduces, while estrogen replacement increases urinary citrate concentrations $(173,174)$. Superoxide dismutase 1 and 2 (SOD1 and SOD2) and catalase (CAT) mRNA expression is higher in the kidneys of female than of male rats. Furthermore, ovariectomy and testosterone treatment in female rats reduced the mRNA expression of all three enzymes. In contrast, male rats treated with estradiol showed an increased expression of SOD1, SOD2, and CAT, while castration up-regulated the expression of SOD2 and CAT, thus suggesting that female rats have a higher capability of coping with oxalate-induced oxidative stress (167).

In addition to sex hormones, other hormones and their receptors may also be indirectly tied to oxalate trafficking in the organism. Notably, in rats during CRF, when oxalate secretion was partially redirected to the intestine, colonic oxalate secretion was regulated by angiotensin II (Ang II type I (AT1)) receptors. The expression of AT1 receptors and oxalate excretion was $\sim 2$-fold higher in the colonic mucosa of rats suffering from CRF. Similar results were obtained by applying Ang II to cultured colonic cells. Furthermore, in a rat model of CRF, oxalate excretion in the colon could be reverted by administering the AT1 receptor antagonist losartan $(93,180)$. However, this effect was not oxalate specific and affected the trafficking of several ion species, such as $\mathrm{K}^{+}, \mathrm{Cl}^{\text {- }}$, and urate across the colonic membranes (181). On the other hand, this effect was segment specific and occured in the proximal and distal colon, whereas the transport in the 
jejunum and ileum remained unchanged, thus supporting the view that colon is the major substitute for diminished renal oxalate secretion during CRF (182). In addition, in rats having CRF and subsequently treated with oxalate, it was established that some degree of renal insufficiency was needed to activate AT1 receptors and increase colonic oxalate excretion. Treatment of healthy rats with oxalate led to increased colonic excretion without the activation of AT1 receptors, thus indicating that the AT 1 receptors may cause an additional severity in oxaluria (183).

In addition to the hormonal causes of sexdependent oxaluria and nephrolithiasis, some vitamins can also be involved in these manifestations. Male and female rats that were denied vitamin B6 in their food for a period of 6 months showed no sex differences in the formation of renal stones (184). Furthermore, various toxic metals were found to influence the activity of Sat-1. Chromium and mercury interfered with Sat-1 and strongly reduced the transport of inorganic $\mathrm{SO}_{4}{ }_{4}^{2-}$, whereas cadmium or lead had a weak inhibitory or no effect on the transport of inorganic $\mathrm{SO}_{4}{ }^{2-}$, respectively (185). At the present, it is not known if these effects of toxic metals on anion transporters affect oxalate transport and/or the incidence of urolithiasis.

Recent studies pointed out the existing species differences in the activity of certain transporters, such as of CFEX in humans and mice. In mice, this transporter mediates a bidirectional electrogenic oxalate $/ \mathrm{Cl}^{-}$exchange, while in humans, this exchange is electroneutral $(186,197)$. The antiporters in these two species also differ in anion selectivity; the mouse ortholog exhibits a higher affinity for $\mathrm{Cl}^{-}$and $\mathrm{SO}_{4}^{2-}$, whereas both orthologs mediate electroneutral $\mathrm{Cl}^{-} \%$ $\mathrm{HCO}_{3}^{-}\left(\mathrm{OH}^{-}\right)$exchange (186). Research on human SLC26A6 and its variants has revealed that possible subtle differences among variants may be at least partially responsible for susceptibility to oxalate urolithiasis (187).

\section{Conclusions: directions for possible future research}

Although intensive research into urinary stone formation has been conducted since the middle of the $20^{\text {th }}$ century, many aspects of this research have been set aside or simply overlooked due to technical limitations. With recent advances in molecular biology, we are now able to broaden our perspective on this problem. Oxalate-related metabolic pathways in the organism have been well-described, and oxalate transport in the liver and kidneys has been revealed in great detail. However, its transport in the gastrointestinal tract needs additional clarification. The only oxalate transporter with a clear role in the intestine is CFEX, which is responsible for oxalate secretion. On the other hand, the exact route of oxalate uptake from the intestinal lumen into the cells, and entry of oxalate into the blood stream, is still a matter of debate. It is of the outmost clinical importance to characterize the transporters and pathways responsible for the transepithelial movement of oxalate in the intestine. Furthermore, an increasing number of evidence supports the importance of sex hormones for the onset and development of oxalate urolithiasis and this could explain the reason and mechanics of the male-dominant incidence of oxalate urolithiasis in humans. Thus far, relevant research has been based on measuring differences of oxalate concentrations in blood and urine after loading subjects with oxalate, whereas the effects of sex hormones on various aspects of oxalate trafficking, especially on the expression and/or activity of oxalate transporters, only recently became the focus of research. In addition to what is already known about sex differences in Sat-1, further research should be directed to discern the effects of sex hormones on other members of the SLC26 family, especially those expressed in organs vital for the generation and handling of oxalate, e.g., the small intestine, colon, liver, and kidneys. Furthermore, attention should be devoted to other aetiological factors, as well as promoters and inhibitors (listed in Table 1) of urolithiasis.

\section{Acknowledgements}

This work was supported by grant 022-02221482146 from the Ministry of Science, Education and Sports, Republic of Croatia (I.S.).

\section{ABBREVIATIONS}

ADH-1, alcohol dehydrogenase 1; AGAT, alanine glyoxylate aminotransferase; ALDH, aldehyde dehydrogenase; AOX, aldehyde oxidase; AT1, angiotensin type I receptor; BBM, brush border membrane; BLM, basolateral membrane; CAI, crystal adhesion inhibitor; CAT, catalase; $\mathrm{CaOx}$, calcium oxalate; $\mathrm{CaP}$, calcium phosphate; CFEX, chloride/ formate exchanger; $\mathrm{CRF}$, chronic renal failure; DIDS, 4,4'-diisothiocyano-2,2' -stilbenedisulfonic acid; GRHPR, glyoxylate reductase/hydroxypyruvate 
reductase; EG, ethylene glycol; DRA, down-regulated in adenoma; HCBD, hexachloro-1,3-butadiene; HAO1 (Hao-1 in animals), hydroxyacid oxidase 1 (glycolate oxidase); ITI, inter- $\alpha$-inhibitor; KSD, kidney stone disease; KO mice, knockout mice; KOx, potassium oxalate; LDH, lactate dehydrogenase; LLC-PK1, pig kidney epithelial cell line; MDCK, Madin-Darby canine kidney; MCP-1, monocyte chemoattractant protein 1; NHE3, sodium-proton exchanger 3; PAH, $p$-aminohippurate; PCMB, $p$-chloromercuribenzoic acid; PAT-1, putative anion transporter 1; SAT-1 (Sat1 in animals), sulfate anion transporter 1; SITS, 4acetoamido-4-isothiocyano 2, stilbene 2,2' disulfonic acid; RBC, red blood cells; SOD1 and 2, superoxide dismutase 1 and 2; TAT-1, Testis anion transporter 1; WT mice, wild type mice; $\mathrm{XO}$, xantine oxidase

\section{REFERENCES}

1. Bushinsky DA, Coe FL, Moe OW. Nephrolithiasis. In: Brenner BM, editor. The kidney. $8^{\text {th }}$ ed. Vol 2. Philadelphia (PA): Saunders; 2008. p. 1299-1375.

2. Watts RWE. Idiopathic urinary stone disease: possible polygenic aetiological factors. Q J Med 2005;98:241-6. doi: 10.1093/qjmed/hci041

3. Sakhaee K. Nephrolithiasis as a systemic disorder. Curr Opin Nephrol Hypertens 2008;17:304-9. doi: 10.1097/ MNH.0b013e3282f8b34d

4. Coe FL, Parks JH. New insights into pathophysiology and treatment of nephrolithiasis: new research venues. J Bone Miner Res 1997;12:522-33. doi: 10.1359/ jbmr.1997.12.4.522

5. Coe FL, Parks JH. Pathogenesis and treatment of urolithiasis. In: Seldin DW, Giebisch G, editors. The kidney. $3^{\text {rd }}$. ed. Vol II. Philadelphia (PA): Lippincott Williams \& Wilkins; 2000. p. 1841-67.

6. Daudon M, Donsimoni R, Hennequin C, Fellahi S, Le Moel G, Paris M, Troupel S, Lacour B. Sex- and age-related composition of 10617 calculi analyzed by infrared spectroscopy. Urol Res 1995;23:319-26. doi: 10.1007/ BF00300021

7. Yoshida O, Okada Y. Epidemiology of urolithiasis in Japan: a chronological and geographical study. Urol Int 1990;45:10411. doi: $10.1159 / 000281680$

8. Robertson WG, Peacock M. The cause of idiopathic calcium stone disease: hypercalciuria or hyperoxaluria? Nephron 1980;26:105-10. doi: 10.1159/000181963

9. Pak CYC, Adams-Huet B, Poindexter JR, Pearle MS, Peterson $\mathrm{RD}$, Moe OW. Relative effect of urinary calcium and oxalate on saturation of calcium oxalate. Kidney Int 2004;66:2032-7. doi: doi:10.1111/j.1523-1755.2004.00975.x

10. Coe FL, Evan A, Worcester E. Kidney stone disease. J Clin Invest 2005;115:2598-608. PMID: 16200192

11. Williams AW, Wilson DM. Dietary intake, absorption, metabolism and excretion of oxalate. Semin Nephrol 1990;10:2-8. PMID: 2404326
12. Hautman RE. The stomach: a new and powerful oxalate absorption site in man. J Urol 1993;149:1401-4. PMID: 8501776

13. Chen Z, Ye Z, Zeng L, Yang W. Clinical investigation on gastric oxalate absorption. Chin Med J 2003;116:1749-51. PMID:14642151

14. Hagler L, Herman RH. Oxalate metabolism. Am J Clin Nutr 1973;26:758-65. PMID: 4576881

15. Singh PP, Kothari LK, Sharma DC, Saxena SN. Nutritional value of foods in relation to their oxalic acid conetent. Am J Clin Nutr 1972;25:1147-52. PMID: 5086037

16. Brinkley L, McGuire J, Gregory J, Pak CY. Bioavailability of oxalate in foods. Urology 1981;17:534-8. PMID: 7245443

17. Caliskan M. The metabolism of oxalic acid. Turk J Zoo 2000;24:103-6.

18. Tang M, Larson-Meyer E, Liebman M. Effect of cinnamon and turmeric on urinary oxalate excretion, plasma lipids, and plasma glucose in healthy subjects. Am J Clin Nutr 2008;87:1262-7. PMID: 18469248

19. Trinchieri A, Mandressi A, Luongo P, Longo G, Pisani E. The influence of diet on urinary risk factors for stones in healthy subjects and idiopathic renal calcium stone formers. Br J Urol 1991;67:230-6. PMID: 2021806

20. Prenen JAC, Boer P, Dorhout-Mess EJ. Absorption kinetics of oxalate from oxalate-rich food in man. Am J Clin Nutr 1984;40:1007-10. PMID: 6496379

21. Holmes RP, Goodman HO, Assimos DG. Dietary oxalate and its intestinal absorption. Scanning Microsc 1995;9:1109-20. PMID: 8819892

22. Holmes RP, Assimos DG. The impact of dietary oxalate on kidney stone formation. Urol Res 2004;32:311-6. PMID: 15221245

23. Holmes RP, Goodman HO, Assimos DG. Contribution of dietary oxalate to urinary oxalate excretion. Kidney Int 2001;59:270-6. doi: 10.1046/j.1523-1755.2001.00488.x

24. Holmes RP, Kennedy M. Estimation of the oxalate content of foods and daily oxalate intake. Kidney Int 2000;57:16627. doi:10.1046/j.1523-1755.2000.00010.x

25. Siener R, Ebert D, Nicolay C, Hesse A. Dietary risk factors for hyperoxaluria in calcium oxalate stone formers. Kidney Int 2003;63:1037-43. doi: 10.1046/j.1523-1755.2003.00807. $\mathrm{x}$

26. Tiselius HG, Ahistrand C, Lundström B, Nilsson MA. $\left[{ }^{14} \mathrm{C}\right]$ Oxalate Absorption by normal persons, calcium oxalate stone formers, and patients with surgically disturbed intestinal function. Clin Chem 1981;27:1682-5. PMID: 7285319

27. Dawson KA, Allison MJ, Hartman PA. Isolation and some characteristics of anaerobic oxalate-degrading bacteria from the rumen. Appl Environ Microbiol 1980;40:833-9. PMID: 7425628

28. Allison MJ, Cook HM, Milne DB, Gallagher S, Clayman RV. Oxalate degradation by gastrointestinal bacteria from humans. J Nutr 1986;116:455-60. PMID: 3950772

29. Argenzio RA, Liacos JA, Allison MJ. Intestinal oxalatedegrading bacteria reduce oxalate absorption and toxicity in guinea pigs. J Nutr 1988;118:787-92. PMID: 3373343

30. Kaufman DW, Kelly JP, Curhan GC, Anderson TE, Dretler SP, Preminger GM, Cave DR. Oxalobacter formigenes may reduce the risk of calcium oxalate kidney stones. J Am Soc Nephrol 2008;19:1197-203. doi: 10.1681/ ASN.2007101058 
31. Zarembski PM, Hodgkinson A. Some factors influencing the urinary excretion of oxalic acid in man. Clin Chim Acta 1969;25:1-10. PMID: 4978800

32. Unruh GEV, Voss S, Sauerbruch T, Hesse A. Dependence of oxalate absorption on the daily calcium intake. J Am Soc Nephrol 2004;15:1567-73. PMID: 15153567

33. Hanes DA, Weaver CM, Heany RP, Wastney M. Absorption of calcium oxalate does not require dissociation in rats. J Nutr 1999;129:170-3. PMID: 9915895

34. Liebman M, Chai W. Effect of dietary calcium on urinary oxalate excretion after oxalate loads. Am J Clin Nutr 1997;65:1453-9. doi: 10.1016/0002-8223(93)91530

35. Liebman M, Costa G. Effects of calcium and magnesium on urinary oxalate excretion after oxalate loads. J Urol 2000;163:1565-9. doi: PMID: 10751889

36. Saunders DR, Sillery J, McDonald GB. Regional differences in oxalate absorption by rat intestine: evidence for excessive absorption by the colon in steatorrhoea. Gut 1975;16:543-8. PMID: 1158192

37. Caspary WF, Tonissen J, Lankisch PG. "Enteral" hyperoxaluria. Effect of cholesyramine, calcium, neomycin, and bile acids on intestinal oxalate absorption in man. Acta Hepatogastroenterol 1977;24:193-200. PMID: 883468

38. Saso L, Grippa E, Gatto MT, Silvestrini B. Inhibition of calcium oxalate precipitation by bile salts. Int J Urol 2001;8:124-7. PMID: 11260337

39. Taylor EN, Curhan GC. Oxalate intake and the risk for nephrolithiasis. J Am Soc Nephrol 2007;18:2198-204. doi: 10.1681/ASN.2007020219

40. Poore RE, Hurst CH, Assimos DG, Holmes RP. Pathways of hepatic oxalate synthesis and their regulation. Am J Physiol Cell Physiol 1997;272:C289-94. PMID: 9038835

41. Yanagawa M, Maeda-Nakai E, Yamakawa K, Yamamoto I, Kawamura J, Tada S, Ichiyama A. The formation of oxalate from glycolate in rat and human liver. Biochim Biophys Acta 1990;1036:24-33. PMID: 2223823

42. Miller H, Barceloux DG, Krenzelok EP, Olson K, Watson W. American academy of clinical toxicology practice guidelines on the treatment of ethylene glycol poisoning. Clin Toxicol 1999;37:537-60. PMID: 10497633

43. Langman CB. The molecular basis of kidney stones. Curr Opin Pediatr 2004;16:188-93. PMID: 15021200

44. Richardson KE, Tolbert NE. Oxidation of glyoxylic acid to oxalic acid by glycolic acid oxidase. J Biol Chem 1961;236:1280-4. PMID: 13741299

45. Haimovici J, Beck JS, Molla-Hosseini C, Vallerand D, Haddad P. Different modulation of hepatocellular $\mathrm{Na}^{+} / \mathrm{H}^{+}$ exchange activity by insulin and EGF. Am J Physiol Gastrointest Liver Physiol 1994;267:G364-70. PMID: 7943232

46. Selvam R. Calcium oxalate stone disease: role of lipid peroxidation and antioxidants. Urol Res 2002;30:35-47. PMID: 11942324

47. Finlayson B. Physicochemical aspects of urolithiasis. Kidney Int 1978;13:344-60. doi: 10.1038/ki.1978.53

48. Verkoelen CF, Van Der Boom BG, Houtsmuller AB, Schröder $\mathrm{FH}$, Romijn JC. Increased calcium oxalate monohydrate crystal binding to injured renal tubular epithelial cells in culture. Am J Physiol Renal Physiol 1998;274:F958-65. PMID: 9612335

49. Phulwinder KG, Thurgood LA, Ryall RL. Effect of urine fractionation on attachment of calcium crystals to renal epithelial cells: implications for studying renal calculogenesis. Am J Physiol Renal Physiol 2007;292:F1396-403. doi: 10.1152/ajprenal.00456.2006

50. Gambaro G, Valente ML, Zanetti E, Barbera MD, Del Prete D, D'Angelo A, Trevisan A. Mild tubular damage induces calcium oxalate crystalluria in a model of subtle hyperoxaluria: evidence that a second hit is necessary for renal lithogenesis. J Am Soc Nephrol 2006;17:2213-9. PMID: 16790510

51. Hackett RL, Shevock PN, Khan SR. Madin-Darby canine kidney cells are injured by exposure to oxalate and to calcium oxalate crystals. Urol Res 1994;22:197-203. PMID: 7871629

52. Scheid C, Koul H, Hill WA, Luber-Narod J, Kennington L, Honeyman T, Jonassen J, Menon M. Oxalate toxicity in LLC-PK 1 cells: role of free radicals. Kidney Int 1996;49:4139. doi: 10.1038/ki.1996.60

53. Thamilselvan S, Byer KJ, Hackett RL, Khan SR. Free radical scavengers, catalase and superoxide dismutase provide protection from oxalate-associated injury to LLC-PK 1 and MDCK sells. J Urol 2000;164:224-9. PMID: 10840464

54. Grases F, Garcia-Ferragut L, Costa-Bauzá A. Development of calcium oxalate crystals on urothelium: effect of free radicals. Nephron 1998;78:296-301. doi: 10.1159/000044939

55. Thamilselvan S, Hackett RL, Khan SR. Lipid peroxidation in ethylene glycol induced hyperoxaluria and calcium oxalate nephrolithiasis. J Urol 1997;157:1059-63. PMID: 9072543

56. Huang HS, Chen CF, Chien CT, Chen J. Possible biphasic changes of free radicals in ethylene glycol-induced nephrolithiasis in rats. BJU Int 2000;85:1143-9. PMID: 10848711

57. Huang HS, Ma MC, Chen J, Chen CF. Changes in oxidantantioxidant balance in the kidney of rats with nephrolithiasis induced by ethylene glycol. J Urol 2002;167:2584-93. doi: 10.1016/S0022-5347(05)65042-2

58. Huang HS, Ma MC, Chen J, Chen CF. Changes in renal hemodynamycs and urodynamics in rats with chronic hyperoxaluria and after acute oxalate infusion: role of free radicals. Neurourol Urodynam 2003;22:176-82. PMID: 12579636

59. Umekawa T, Chegini N, Khan SR. Oxalate ions and calcium oxalate crystals stimulate MCP-1 expression by renal epithelial cells. Kidney Int 2002;61:105-12. doi: 10.1046/ j.1523-1755.2002.00106.x

60. Umekawa T, Chegini N, Khan SR. Increased expression of monocyte chemoattractant protein-1 (MCP-1) by renal epithelial cells in culture on exposure to calcium oxalate, phosphate, and uric acid crystals. Nephrol Dial Transplant 2003;18:664-9. doi: 10.1093/ndt/gfg140

61. Umekawa T, Byer K, Uemura H, Khan SR. Diphenyleneiodium (DPI) reduces oxalate ion- and calcium oxalate monohydrate and brushite crystal-induced upregulation of MCP-1 in NRK52E cells. Nephrol Dial Transplant 2005;20:870-8. doi: $10.1093 /$ ndt/gfh750

62. Lieske JC, Leonard R, Toback FG. Adhesion of calcium oxalate monohydrate crystals to renal epithelial cells is inhibited by specific anions. Am J Physiol Renal Fluid Electrolyte Physiol 1995;268:F604-12. PMID: 8769839

63. Kumar V, Yu S, Farell G, Toback FG, Lieske JC. Renal epithelial cells constitutively produce a protein that blocks adhesion of crystals to their surface. Am J Physiol Renal 
Physiol 2004;287:F372-83. doi: 10.1152/ ajprenal.00418.2003

64. Wesson JA, Worcester EM, Wiessner JH, Mandel NS, Kleinman JG. Control of calcium oxalate crystal structure and cell adherence by urinary macromolecules. Kidney Int 1998;53:952-7. doi: 10.1111/j.1523-1755.1998.00839.x

65. Yagisawa T, Chandhoke PS, Fan J, Lucia S. Renal osteopontin expression in experimental urolithiasis. J Endourol 1998;12:171-6. PMID: 9607445

66. Khan SR, Johnson JM, Peck AB, Cornelius JG, Glenton PA Expression of osteopontin in rat kidneys: induction during ethylene glycol induced calcium oxalate nephrolithiasis. J Urol 2002;168:1173-81. doi: 10.1097/01 . ju.0000024398.45396.6c

67. Sokalingum NP, Asplin JR, Coe FL. Evidence that calgranulin is produced by kidney cells and is inhibitor of calcium oxalate crystallization. Am J Physiol Renal Physiol 1998;275:F25561. PMID: 9691016

68. Hess B, Jordi S, Zipperle LJ, Ettinger E, Giovanoli R. Citrate determines calcium oxalate crystallization kinetics and crystal morphology - studies in the presence of TammHorsfall protein of a healthy subject and severely recurrent calcium stone former. Nephrol Dial Transplant 2000;15:36674. doi: $10.1093 / \mathrm{ndt} / 15.3 .366$

69. Grover PK, Thurgood LA, Fleming DE, van Bronswijk W, Wang T, Ryall RL. Intracrystalline urinary proteins facilitate degradation and dissolution of calcium oxalate crystals in cultured renal cells. Am J Physiol Renal Physiol 2008;294: F355-61. doi: 10.1152/ajprenal.00529.2007

70. Atmani F, Khan SR. Characterization of uronic acid-rich inhibitor of calcium crystallization isolated from rat urine. Urol Res 1995;3:95-101. doi: 10.1007/BF00307939

71. Iida S, Peck AB, Johnosn-Tardieu J, Moriyama M, Glenton PA, Byer KJ, Khan Sr. Temporal changes in mRNA expression for Bikunin in the kidneys of rats during calcium oxalate nephrolithiasis. J Am Soc Nephrol 1999;10:986-96. PMID: 10232684

72. Selvam R, Adhirai M. Vitamin E pretreatment prevents cyclosporine A-induced crystal deposition in hyperoxaluric rats. Nephron 1997;75:77-81. doi: 10.1159/000189503

73. Reckelhoff JF, Kanji V, Racusen LC, Schmidt AM, Yan SD, Morrow J, Roberts LJ, Salahudeen AK. Vitamin E ameliorates enhanced renal lipid peroxidation and accumulation of F2isoprostanes in aging kidneys. Am J Physiol Regul Integr Comp Physiol 1998;274:R767-74. PMID: 9530244

74. Huang HS, Chen J, Chen CF, Ma MC. Vitamin E attenuates crystal formation in rat kidneys: role of renal tubular cell death and crystallization inhibitors. Kidney Int 2006;70:699710. doi: 10.1038/sj.ki.5001651

75. Huang HS, Ma MC, Chen J. Low vitamin E diet exacerbates calcium oxalate crystal formation via enhanced oxidative stress in rat hyperoxaluric kidney. Am J Physiol Renal Physiol 2009;296:F34-45. doi: 10.1152/ajprenal.90309.2008

76. Gershoff SN, Faragalla FF. Endogenous oxalate synthesis and glycine, serine, deoxypyridoxine interrelationships in vitamin B6-deficient rats. J Biol Chem 1959;234:2391-3. PMID: 13827605

77. Gershof SN, Prien EP, Faragalla FF, Shen GSH, Kearny MM. Excretion of urinary metabolites in calcium oxalate urolithiasis. Effect of tryptophan and vitamin B6 administration. Am J Clin Nutr 1960;8:812-6. PMID 13704750
78. Runyan TJ, Gershoff SN. The effect of vitamin B6 deficiency in rats on the metabolism of oxalic acid precursors. J Biol Chem 1965;240:1889-92. PMID: 14299606

79. Ravichandran V, Selvam R. Increased lipid peroxidation in kidney of vitamin B-6 deficient rats. Biochem Int 1990;21:599605. PMID: 2241985

80. Curhan GC, Willet WC, Speizer FE, Stamper MJ. Inatke of vitamin $\mathrm{B} 6$ and $\mathrm{C}$ and the risk of kidney stones in women. J Am Soc Nephrol 1999;10:840-5. PMID: 10203369

81. Ribaya JD, Gershoff SN. Effects of hydroxyproline and vitamin B-6 on oxalate synthesis in rats. J Nutr 1981;111:12319. PMID: 6788912

82. Sakly R, Achour A, Zouaghi H. Etude sur l'action antilithogène et litholytique de la vitamine $\mathrm{A}$ vis-à-vis de la lithiase expérimentale chez le rat [Antilithogenic and litholytic action of vitamin A vis-à-vis experimental calculi in rats, in French]. Ann Urol (Paris) 1994;28:128-31.

83. Urivetzky M, Kessaris D, Smith AD. Ascorbic acid overdosing: a risk factor for calcium oxalate. J Urol 1992;147:1215-8. PMID: 1569652

84. Massey LK, Liebman M, Kynast-Gales SA. Ascorbate increases human oxaluria and kidney stone risk. J Nutr 2005;135:1673-7. PMID: 15987848

85. Ribaya-Mercado JD, Gershoff SN. Effects of sugars and vitamin B-6 deficiency on oxalate synthesis in rats. J Nutr 1984;114:1447-53. PMID: 6747727

86. Welshman SG, McGeown MG. Urinary citrate excretion in stone-formers and normal controls. Br J Urol 1976;48:7-11. doi: 10.1111/j.1464-410X.1976.tb02731.x

87. Osther PJ. [Citrate and kidney stones, in Danish]. Ugeskr Laeger 1993;155:3835-9. PMID: 8256384

88. Rudman D, Kutner MH, Redd SC, Waters WC, Gerron GG, Bleier J. Hypocitraturia in calcium nephrolithiasis. J Clin Endocrinol Metab 1982;55:1052-7. PMID: 7130336

89. Cowley DM, McWhinney BC, Brown JM, Chaimers AH. Effect of citrate on the urinary excretion of calcium and oxalate: relevance to calcium oxalate nephrolithiasis. Clin Chem 1989;35:23-8. PMID: 2910576

90. Goldberg H, Grass L, Vogl R, Rapaport A, Oreopoulos DG. Urine citrate and renal stone disease. Can Med Assoc J 1989;141:217-21. PMCID: PMC1269410

91. Tiselius HG, Berg C, Fornander AM, Nilsson MA. Effects of citrate on the different phases of calcium oxalate crystallization. Scanning Microsc 1993;7:381-90. PMID: 8316807

92. Mount DB, Romero MF. The SLC26 gene family of multifunctional anion exchangers. Pflugers Arch - Eur J Physiol 2004;447:710-21. doi: 10.1007/s00424-003-10903

93. Hatch M, Freel RW. Intestinal transport of an obdurate anion: oxalate. Urol Res 2005;33:1-16. PMID: 15565438

94. Sindic A, Chang MH, Mount DB, Romero MF. Renal physiology of SLC26 anion exchangers. Curr Opin Nephrol Hypertens 2007;16:484-90. PMID: 17693766

95. Dorwart MR, Shcheynikov N, Yang D, Muallem S. The solute carrier 26 family of proteins in epithelial ion transport. Physiology 2008;23:104-14. doi: 10.1152/ physiol.00037.2007

96. Quandamatteo F, Krick W, Schubert K, Brzica H, Balen D, Sabolic I, Burckhardt G, Burckhardt BC. Localization of sat-1 (slc26a6) along the gastrointestinal tract. Acta Physiol 2007;189 (Suppl 653):56 . 
97. Wang Z, Petrovic S, Mann E, Soleimani M. Identification of an apical $\mathrm{Cl}^{-} / \mathrm{HCO}_{3}^{-}$exchanger in the small intestine. Am J Physiol Gastrointest Liver Physiol 2002;282:G573-9. doi: 10.1152/ajpgi.00338.2001

98. Xie Q, Welch R, Mercado A, Romero MF, Mount DB. Molecular characterization of the murine Slc26a6 anion exchanger: functional comparison with Slc26a1. Am J Physiol Renal Physiol 2002;283:F826-38. doi: 10.1152/ ajprenal.00079.2002

99. Petrovic S, Wang Z, Ma L, Seidler U, Forte JG, Shull GE, Soleimani M. Colocalization of the apical $\mathrm{Cl}^{-} / \mathrm{HCO}_{3}$ exchanger PAT1 and gastric H-K-ATPase in stomach parietal cells. Am J Physiol Gastrointest Liver Physiol 2002;283: G1207-16. PMID: 12381535

100. Petrovic S, Ju X, Barone S, Siedler U, Alper SL, Lohi H, Kere J, Soleimani M. Identification of a basolateral $\mathrm{Cl}^{-} / \mathrm{HCO}$ exchanger specific to gastric parietal cells. Am J Physiol Gastrointest Liver Physiol 2003;284:G1093-103. doi: 10.1152/ajpgi.00454.2002

101. Hofmann AF, Laker MF, Dharmsathaphorn K, Sherr HP, Lorenzo D. Complex pathogenesis of hyperoxaluria after jejunoileal bypass surgery. Oxalogenic substances in diet contribute to urinary oxalate. Gastroenterology 1983;84:293300. PMID: 6848409

102. Hatch M, Freel RW, Goldner AM, Earnest DL. Oxalate and chloride absorption by the rabbit colon: sensitivity to metabolic and anion transport inhibitors. Gut 1984;25:232-7. doi: 10.1136/gut.25.3.232

103. Knickelbein RG, Aronson PS, Dobbins JW. Oxalate transport by anion exchange across rabbit ileal brush border. J Clin Invest 1986;77:170-5. doi: 10.1172/JCI112272

104. Hatch M, Freel RW, Vaziri ND. Characteristics of the transport of oxalate and other ions across rabbit proximal colon. Pflugers Arch - Eur J Physiol 1993;423:206-12. doi: 10.1007/BF00374396

105. Hatch M, Freel RW, Vaziri ND. Mechanisms of oxalate absorption and secretion across the rabbit distal colon. Pflugers Arch - Eur J Physiol 1994;426:101-9. PMID: 8146012

106. Wang Z, Wang T, Petrovic S, Tuo B, Riederer B, Barone S, Lorenz JN, Seidler U, Aronson PS, Soleimani M. Renal and intestinal transport defects in Slc26a6-null mice. Am J Physiol Cell Physiol 2005;288:C957-65. doi: 10.1152/ ajpcell.00505.2004

107. Freel RW, Hatch M, Green M, Soleimani M. Ileal oxalate absorption and urinary oxalate excretion are enhanced in Slc26a6 null mice. Am J Physiol Gastrointest Liver Physiol 2006;290:G719-28. doi: 10.1152/ajpgi.00481.2005

108. Jiang Z, Asplin JR, Evan AP, Rajendran VM, Velazquez H, Nottoli TP, Binder HJ, Aronson PS. Calcium oxalate urolithiasis in mice lacking anion transporter Slc26a6. Nat Genet 2006;38:474-8. PMID: 16532010

109. Soleimani M. The role of SLC26A6-mediated chloride/ oxalate exchange in causing susceptibility to nephrolithiasis. J Physiol 2008;586:1205-6. doi: 10.1113/ jphysiol.2007.150565

110. Hatch M, Freel RW, Vaziri ND. Intestinal excretion of oxalate in chronic renal failure. J Am Soc Nephrol 1994;5:1339-43. PMID: 7893999

111. Freel RW, Hatch M, Vaziri ND. Conductive pathways for chloride and oxalate in rabbit ileal brush-border membrane vesicles. Am J Physiol Cell Physiol 1998;275:C748-57. PMID: 9730958

112. Lee A, Beck L, Markovich D. The mouse sulfate anion transporter gene sat1 (Slc26a6): cloning, tissue distribution, gene structure, functional characterization, and transcriptional regulation by thyroid hormone. DNA Cell Biol 2003;22:1931. doi: $10.1089 / 104454903321112460$

113. Regeer RR, Lee A, Markovich D. Characteriaztion of the human sulfate anion transporter (hsat-1) protein and gene. DNA Cell Biol 2003;22:107-17. PMID: 12713736

114. Hatch M, Freel RW. The roles and mechanisms of intestinal oxalate transport in oxalate homeostasis. Semin Nephrol 2008;28:143-51. doi: 10.1016/j.semnephrol.2008.01.007

115. Robijn S, Hoppe B, Vervaet BA, D'Haese PC, Verhulst A. Hyperoxaluria: a gut-kidney axis? Kidney Int 2011;80:114658. doi: 10.1038/ki.2011.287

116. Quondamatteo F, Krick W, Hagos Y, Krüger MH, NeubauerSaile K, Herken R, Ramadori G, Burckhardt G, Burckhardt $\mathrm{BC}$. Localization of sulfate/anion exchanger in the rat liver. Am J Physiol Gastrointest Liver Physiol 2006;290:G1075-81. doi: 10.1152/ajpgi.00492.2005

117. Brzica H, Breljak D, Krick W, Lovric M, Burckhardt G, Burckhardt BC, Sabolic I. The liver and kidney expression of sulfate anion transporter sat-1 in rats exhibits maledominant gender differences. Pflugers Arch Eur J Physiol 2009;457:1381-92. doi: 10.1007/s00424-008-0611-5

118. Karniski LP, Lötscher M, Fucentese M, Hilfiker H, Biber J, Murer H. Immunolocalization of sat-1 sulfate/oxalate/ bicarbonate anion exchanger in the rat kidney. Am J Physiol Renal Physiol 1998;275:F79-87. PMID: 9689008

119. Brzica H, Balen D, Breljak D, Ljubojevic M, Zlender V, Burckhardt BC, Burckhardt G, Sabolic I. Immunolocalization of $\mathrm{Na}^{+}$-independent sulfate transporter Sat-1 (Slc26a1) in rat kidney and gastrointestinal tract. Period Biol 2007;109(Suppl 2): 148 .

120. Ko N, Knauf F, Jiang Z, Markovich D, Aronson PS. Sat1 is dispensable for active oxalate secretion in mouse duodenum. Am J Physiol Cell Physiol 2012;303:C52-7. doi: 10.1152/ ajpcell.00385.2011

121. Silberg DG, Wang W, Moseley H, Traber PG. The down regulated in adenoma (dra) gene encodes intestine-specific membrane sulfate transporter protein. J Biol Chem 1995;270:11897-902. doi: 10.1074/jbc.270.20.11897

122. Byeon MK, Frankel A, Papas TS, Henderson KW, Schweinfest CW. Human DRA functions as a sulfate transporter in Sf9 insect cells. Protein Expr Purif 1998;12:6774. PMID: 9473459

123. Jacob P, Rosmann H, Lamprecht G, Kretz A, NeffC, Lin-Wu E, Gregor M, Groneberg DA, Kere J, Sedler U. Downregulated in adenoma mediates apical $\mathrm{Cl}^{-} / \mathrm{HCO}^{-}$exchange in rabbit, rat, and human duodenum. Gastroenterology 2002;122:709-24. doi: 10.1053/gast.2002.31875

124. Schweinfest CW, Spyropoulos DD, Henderson KW, Kim JH, Chapman JM, Barone S, Worell RT, Wang Z, Soleimani M. slc26a3 (dra)-deficient mice display chloride-losing diarrhea, enhanced colonic proliferation and distinct up-regulation of ion transporters in the colon. J Biol Chem 2006;281:3796271. doi: $10.1074 / \mathrm{jbc}$.M607527200

125. Hoglund P, Halia S, Socha J, Tomaszewski I, Saarialho-Kere U, Karjalainen-Lindsberg ML, Airola K, Holmerg C, de la Chapelle A, Kere J. Mutations of the down-regulated in 
adenoms (DRA) gene cause congenital chloride diarrhoea. Nat Genet 1996;14:316-9. doi: 10.1038/ng1196-316

126. Haila S, Saarialho-Kere U, Karjalainen-Lindsberg ML, Lohi H, Airola K, Holmberg C, Hastbacka J, Kere J, Hoglund P. The congenital chloride diarrhea gene is expressed in seminal vesicle, sweat gland, inflammatory colon epithelium, and in some dysplastic colon cells. Histochem Cell Biol 2000;113:279-86. PMID: 10857479

127. Freel RW, Morozumi M, Hatch M. Parsing apical oxalate exchange in Caco-2BBel monolayers: siRNA knockdown of SLC26A6 reveals the roles and properties of PAT-1. Am J Physiol Gastrointest Liver Physiol 2009;297:G918-G929.

128. Heneghan JF, Akhvaein A, Salas M, Shmukler BE, Karniski LP, Vandorpe DH, Alper SL. Regulated transport of sulfate and oxalate by SLC26A2/DTDST. Am J Physiol Cell Physiol 2010;298:C1363-75. doi: 10.1152/ajpcell.00004.2010

129. Hugentobler G, Meier PJ. Multispecific anion exchange in basolateral (sinusoidal) rat liver plasma membrane vesicles. Am J Physiol Gastrointest Liver Physiol 1986;251:G656-64. PMID: 3777171

130. Bissig M, Hagenbuch B, Stieger B, Koller T, Meier PJ. Functional expression cloning of the canalicular sulfate transport system of rat hepatocytes. J Biol Chem 1994;269:3022-6. PMID: 8300633

131. Krick W, Schnedler N, Burckhardt G, Burckhardt BC. Ability of sat-1 to transport sulfate, bicarbonate, or oxalate under physiological conditions. Am J Physiol Renal Physiol 2009;297:145-54. doi: 10.1152/ajprenal.90401.2008

132. Cattell WR, Spencer AG, Taylor GW, Watts RWE. The mechanism of the renal oxalate excretion in the dog. Clin Sci 1962;22:43-52. PMID: 13877395

133. Williams HE, Johnson GA, Smith LH. The renal clearance of oxalate in normal subjects and patients with primary hyperoxaluria. Clin Sci 1971;41:213-8. PMID: 5571501

134. McIntosh GH, Belling GB. An isotopic study of oxalate excretion in sheep. Aust J Exp Biol Med Sci 1975;53:479-87. PMID: 1230144

135. Greger R, Lang F, Oberleithner H, Deetjen P. Handling of oxalate by the rat kidney. Pflugers Arch 1978;374:243-8. doi: 10.1007/BF00585601

136. Weinman EJ, Frankfurt SJ, Ince A, Sansom S. Renal tubular transport of organic acids. J Clin Invest 1978;61:801-6. doi: 10.1172/JCI108994

137. Knight TF, Senekjian HO, Weinman EJ. Effect of paraaminohippurate on renal transport of oxalate. Kidney Int 1979;15:38-42. doi: 10.1038/ki.1979.5

138. Knight TF, Sansom SC, Senekjian HO, Weinman EJ. Oxalate secretion in the rat proximal tubule. Am J Physiol Renal Fluid Electrolyte Physiol 1981;240:F295-8. PMID: 7223887

139. Senekjian HO, Weinman EJ. Oxalate transport by proximal tubule of the rabbit kidney. Am J Physiol Renal Fluid Electrolyte Physiol 1982;243:F271-5. PMID: 7114257

140. Löw I, Friedrich T, Burckhardt G. Properties of an anion exchanger in rat renal basolateral membrane vesicles. Am J Physiol Renal Fluid Electrolyte Physiol 1984;246:F334-42. PMID: 6703066

141. Hagenbuch B, Stange G, Murer H. Transport of sulphate in rat jejuna and rat proximal tubular basolateral membrane vesicles. Pflugers Arch 1985;405:202-8. doi: 10.1007/ BF00582561
142. Kuo SM, Aronson PS. Oxalate transport via the sulfate/ $\mathrm{HCO}_{3}$ exchanger in rabbit renal basolateral membrane vesicles. J Biol Chem 1988;263:9710-7. PMID: 3384817

143. Markovich D, Bissig M, Sorribas V, Hagenbuch B, Meier $\mathrm{PJ}$, Murer H. Expression of rat renal sulfate transport systems in Xenopus Laevis oocytes. J Biol Chem 1994;269:3022-6. PMID: 8300634

144. Brändle E, Bernt U, Hautmann RE. In situ characterization of oxalate transport across the basolateral membrane of the proximal tubule. Pflugers Arch 1998;435:840-9. 10.1007/ s004240050592

145. Karniski LP, Aronson PS. Chloride/formate exchange with formic acid recycling: a mechanism of active chloride transport across epithelial membranes. Proc Natl Acad Sci USA 1985;82:6362-5. PMCID: PMC391054

146. Karniski LP, Aronson PS. Anion exchange pathways for $\mathrm{Cl}^{-}$ transport in rabbit renal microvillus membranes. Am J Physiol Renal Fluid Electrolyte Physiol 1987;253:F513-21. PMID: 3631282

147. Koul H, Ebisuno S, Renzulli L, Yanagawa, Menon M, Scheid C. Polarized distribution of oxalate transport systems in LLC-PK1 cells, a line of renal epithelial cells. Am J Physiol Renal Fluid Electrolyte Physiol 1994;266:F266-74. PMID: 8141327

148. Kuo SM, Aronson PS. Pathways for oxalate transport in rabbit renal microvillus membrane vesicles. J Biol Chem 1996;271:15491-7. PMID: 8663096

149. Knauff F, Yang CL, Thomson RB, Mentone SA, Giebisch G, Aronson PS. Identification of a chloride-formate exchanger expressed on the brush border membrane of renal proximal tubule cells. Proc Natl Acad Sci USA 2001;98:9425-30. doi: 10.1073/pnas. 141241098

150. Jiang Z, Grichtchenko II, Boron WF, Aronson PS. Specifity of anion exchange mediated by mouse Slc26a6. J Biol Chem 2002;277:33963-7. PMID: 12119287

151. Wang T, Egbert AL, Abbiati T, Aronson PS, Giebisch G. Mechanisms of stimulation of proximal tubule chloride transport by formate and oxalate. Am J Physiol Renal Fluid Electrolyte Physiol 1996;271:F446-50. PMID: 8770178

152. Aronson PS. Essential roles of CFEX-mediated $\mathrm{Cl}^{-}$-oxalate exchange in proximal tubule $\mathrm{NaCl}$ transport and prevention of urolithiasis. Kidney Int 2006;70:1207-13. doi: 10.1038/ sj.ki.5001741

153. Markovich D. Slc13a1 and Slc26a1 KO models reveal physiological roles of anion transporters. Physiology 2012;27:7-14. doi: 10.1152/physiol.00041.2011

154. Laski ME, Kurtzman NA, Sabatini S. Chronic renal failure. In: Seldin DW, Giebisch G, editors. The Kidney, $3^{\text {rd }}$ ed. Vol II. Philadelphia (PA): Lippincott Williams \& Wilkins; 2000. p. $2375-409$

155. Costello J, Smith M, Stolarski C, Sadovnic MJ. Extrarenal clearance of oxalate increases with progression of renal failure in the rat. J Am Soc Nephrol 1992;3:1098-104. PMID: 1482750

156. Fernandes I, Laouari D, Tutt P, Hampson G, Friedlander G, Silve C. Sulfate homeostasis, NaSi-1 cotransporter, and SAT1 exchanger in chronic renal failure in rats. Kidney Int 2001;59:210-21. doi: 10.1046/j.1523-1755.2001.00481.x

157. Khan SR, Glenton PA. Calcium oxalate crystal deposition in kidneys of hypercalciuric mice with disrupted type IIa sodium-phosphate cotransporter. Am J Physiol Renal Physiol 2008;294:F1109-15. doi: 10.1152/ajprenal.00620.2007 
158. Koutsoukos PG, Sheehan ME, Nancollas GH. Epitaxial considerations in urinary stone formation II. The oxalatephosphate system. Invest Urol 1981;18:358-63. PMID: 7203960

159. Evan AP, Lingeman JE, Coe FL, Parks JH, Bledsoe SB, Shao Y, Sommer AJ, Paterson RF, Kuo RL, Grynpas M. Randall's plaque of patients with nephrolithiasis begins in basement membranes of thin loops of Henle. J Clin Invest 2003;111:60716. doi: 10.1172/JCI200317038

160. He Y, Chen X, Yu Z, Wu D, Lv Y, Shi S, Zhu H. Sodium dicarboxylate cotransporter-1 expression in renal tissues and its role in rat experimental nephrolithiasis. J Nephrol 2004;17:34-42. PMID: 15151257

161. Kohri K, Ishikawa Y, Katoh Y, Kataoka K, Iguchi M, Yachiku S, Kurita T. Epidemiology of urolithiasis in the elderly. Int Urol Nephrol 1991;23:413-21. PMID: 1938239

162. Dall'era J, Kim F, Chandhoke PS. Gender differences among Hispanics and Caucasians in symptomatic presentation of kidney and ureteral stones. J Endourol 2005;159:283-6. PMID: 15865513

163. Costa-Bauzá A, Ramis M, Montesinos V, Conte A, Pizá P, Pieras P, Grases F. Type of renal calculi: variation with age and sex. World J Urol 2007;25:415-21. doi. 10.1007/s00345007-0177-4

164. Lemann J, Pleuss JA, Worcester EM, Hornick L, Schrab D, Hoffman RG. Urinary oxalate excretion increases with body size and decreases with increasing dietary calcium intake among healthy adults. Kidney Int 1996;49:200-8. PMID: 8770968

165. Daudon M, Lacour B, Jungers P. Influence of body size on urinary stone composition in men and women. Urol Res 2006;34:193-9. PMID: 16474948

166. Lee YH, Huang WC, Huang JK, Chang LS. Testosterone enhances whereas estrogen inhibits calcium oxalate stone formation in ethylene glycol treated rats. JUrol 1996;156:5025. doi: 10.1097/00005392-199608000-00071

167. Yoshihara H, Yamaguchi S, Yachiku S. Effect of sex hormones on oxalate-synthesizing enzymes in male and female rat livers. J Urol 1999;161:668-73. doi: 10.1097/00005392-199902000-00097

168. Dembic Z, Sabolic I. Alcohol dehydrogense activity in rat kidney cortex stimulated by oestradiol. Biochim Biophys Acta 1982;714:331-6. doi: 10.1016/0304-4165(82)90341-5

169. Qulali M, Ross RA, Crabb DW. Estradiol induces class I alcohol dehydrogenase activity and mRNA in kidney of female rats. Arch Biochem Biophys1991;288:406-13. PMID: 1716872

170. Harada S, Tachiyashiki K, Imaizumi K. Effect of sex hormones on rat liver cytosolic alcohol dehydrogenase activity. J Nutr Sci Vitaminol 1998;44:625-39. PMID: 9919483

171. Rachamin G, Israel Y. Sex differences in hepatic alcohol dehydrogenase activity in animal species. Biochem Pharmacol 1985;34:2385-6. PMID: 3160354

172. Simon FR, Fortune J, Iwahashi M, Sutherland E. Sexual dimorphic expression of ADH in rat liver: importance of the hypothalamic-pituitary-liver axis. Am J Physiol Gastrointest Liver Physiol 2002;283:G646-55. PMID: 12181179

173. Yoshioka I, Tsujihata M, Momohara C, Wongsawat A, Nonomura N, Okuyama A. Effect of sex-hormones on crystal formation in a stone-forming rat model. Urology 2010;75:90713. doi: 10.1016/j.urology.2009.09.094
174. Wegner W, Burckhardt BC, Burckhardt G, Henjakovic M. Male-dominant activation of rat renal organic anion transporter 1 (Oat1) and 3 (Oat3) expression by transcription factor BCL6. PLoS ONE 2012;7:e35556. doi: 10.1371/ journal.pone. 0035556

175. Iguchi M, Takamura C, Umekawa T, Kurita T, Kohri K. Inhibitory effects of female sex hormones on urinary stone formation in rats. Kidney Int 1999;56:479-85. PMID: 10432386

176. Sabolic I, Asif AR, Budach WE, Wanke C, Bahn A, Burckhardt G. Gender differences in kidney function. Pflugers Arch - Eur J Physiol 2007;455:397-29. doi: 10.1007/ s00424-007-0308-1

177. Jennings ML, Al-Rhaiyel S. Modification of a carboxyl group that appears to cross the permeability barrier in the red blood cell anion transporter. J Gen Physiol 1988;92:161-78. PMID: 3171537

178. Jennings ML, Adame MF. Characterization of oxalate transport by the human erythrocyte band 3 protein. J Gen Physiol 1996;107:145-59. doi: 10.1085/jgp.107.1.145

179. Gambaro G, Marchini F, Piccoli A, Nassuato MA, Bilora F, Baggio $\mathrm{B}$. The abnormal red-cell oxalate transport is a risk factor for idiopathic calcium nephrolithiasis: a prospective study. J Am Soc Nephrol 1996;7:608-12. PMID: 8724895

180. Hatch M, Freel RW, Vaziri ND. Local upregulation of colonic angiotensin II receptors enhances potassium excretion in chronic renal failure. Am J Physiol Renal Physiol 1998;274: F275-82. PMID: 9486222

181. Hatch M, Freel RW, Shahnifar S, Vaziri ND. Effects of specific angiotensin II receptor antagonist losartan on urate homeostasis and intestinal urate transport. J Pharmacol Exp Ther 1996;276:187-93. PMID: 8558429

182. Hatch M, Freel RW, Vaziri ND. AT1 receptor up-regulation in intestine in chronic renal failure is segment specific. Pflugers Arch - Eur J Physiol 1999;437:881-7. PMID: 10370066

183. Hatch M, Freel RW. Angiotensin II involvement in adaptive enteric oxalate excretion in rats with chronic renal failure induced by hyperoxaluria. Urol Res 2003;31:426-32. PMID: 14574528

184. Gershoff SN. Production of urinary calculi in vitamin B6 deficient male, female and castrated male rats. J Nutrition 1969;100:117-22. PMID: 5412125

185. Markovich D, James KM. Heavy metals mercury, cadmium, and chromium inhibit the activity of the mammalian liver and kidney sulfate transporter sat-1. Toxicol Appl Pharmacol 1999;154:181-7. PMID: 9925802

186. Chernova MN, Jiang L, Friedman DJ, Darman RB, Lohi H, Kere J, Vandorpe DH, Alper SL. Functional comparison of mouse slc26a6 anion exchanger with human SLC26A6 polypeptide variants. J Biol Chem 2005;280:8564-80. PMID: 15548529

187. Clark JS, Vandorpe DH, Chernove MN, Heneghan JF, Stewart AK, Alper SL. Species differences in $\mathrm{Cl}^{-}$affinity and in electrogenicity of SLC26A6-mediated oxalate/ $\mathrm{Cl}^{-}$exchange correlate with the distinct human and mouse susceptibilities to nephrolithiasis. J Physiol 2008;586:1291-306. doi: 10.1113/jphysiol.2007.143222

188. Schnedler N, Burckhardt G, Burckhardt BC. Glyoxylate is a substrate of the sulfate-oxalate exchanger, sat-1, and increases its expression in HepG2 cells. J Hepatol 2011;54:513-20. doi: 10.1016/j.jhep.2010.07.036 


\section{Sažetak}

\section{OKSALAT - OD OKOLIŠA DO BUBREŽNIH KAMENACA}

Oksalatna urolitijaza (nefrolitijaza) najučestaliji je tip bolesti bubrežnih kamenaca. Rezultati epidemioloških istraživanja pokazali su da je urolitijaza približno dvostruko učestalija u muškaraca nego u žena, ali osnovni mehanizam nastanka ove spolno-ovisne prevalencije nije razjašnjen. Oksalat u organizmu dijelom potječe iz hrane (egzogeni oksalat), a glavninom nastaje kao konačni produkt metabolizma raznih preteča u jetrima (endogeni oksalat). Na koncentraciju oksalata u plazmi i urinu utječu razne tvari iz hrane, koje mogu pozitivno ili negativno djelovati na apsorpciju, metaboličke puteve i/ili izlučivanje oksalata. Oksalat se iz organizma izlučuje u manjem obimu putem žuči u crijevo, a glavninom bubrezima. U bubrezima, pri odgovarajućim uvjetima kao što su visoka koncentracija oksalata i oštećenje epitela bubrežnih kanalića, oksalat može precipitirati i time potaknuti stvaranje kamenaca. Rezultati novih istraživanja upućuju na

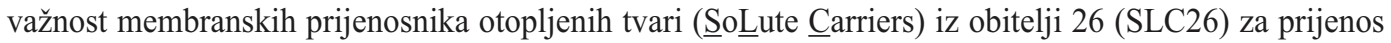
oksalata u specifičnim organima. Smatra se da dva člana ove obitelji: prijenosnik sulfatnog aniona (ulfate Anion Transporter 1; SAT-1; SLC26A1) i izmjenjivač klora i mravlje kiseline (Chloride/Formate EXchanger; CFEX; SLC26A6), imaju značajnu ulogu u prijenosu oksalata u crijevima, jetrima i bubrezima; hiperoksalurija i nefrolitijaza utvrđeni su pri slaboj aktivnosti ili nedostatku SAT-1 i CFEX proteina. Međutim, još uvijek postoje brojne nejasnoće glede prijenosa oksalata u navedenim organima, mehanizma nastanka spolnih razlika u nefrolitijazi i utjecaja spolnih hormona na ekspresiju proteina i mRNA za navedene prijenosnike.

KLJUČNE RIJEČI: bolest bubrežnih kamenaca, CFEX, kalcij, membranski prijenosnici, nefrolitijaza, organski anioni, SAT-1, SLC26A1, SLC26A6, spolne razlike, urolitijaza

\section{CORRESPONDING AUTHOR:}

Hrvoje Brzica, D.V.M., Ph.D.

Department of Anatomy, Histology and Embryology

Faculty of Veterinary Medicine

Heinzlova st. 55, 10000 Zagreb

E-mail:hbrzica@vef.hr 